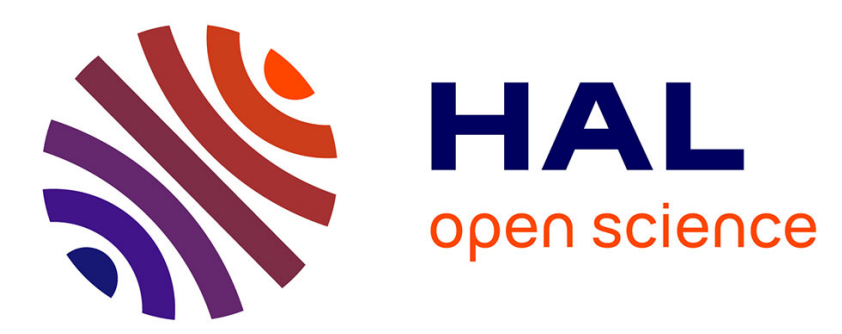

\title{
Neither the elite, nor the mass. The rise of intermediate human capital during the French industrialization process
}

Claude Diebolt, Charlotte Le Chapelain, Audrey Rose Menard

\section{- To cite this version:}

Claude Diebolt, Charlotte Le Chapelain, Audrey Rose Menard. Neither the elite, nor the mass. The rise of intermediate human capital during the French industrialization process. Cliometrica, 2021, 15 (1), pp.167-202. 10.1007/s11698-019-00199-6 . hal-03345552

\section{HAL Id: hal-03345552 \\ https://hal.science/hal-03345552}

Submitted on 15 Sep 2021

HAL is a multi-disciplinary open access archive for the deposit and dissemination of scientific research documents, whether they are published or not. The documents may come from teaching and research institutions in France or abroad, or from public or private research centers.
L'archive ouverte pluridisciplinaire HAL, est destinée au dépôt et à la diffusion de documents scientifiques de niveau recherche, publiés ou non, émanant des établissements d'enseignement et de recherche français ou étrangers, des laboratoires publics ou privés. 


\section{AFC

\section{WORKING PAPERS}

\section{Nr. 4, 2019}

Neither the elite, nor the mass.

The rise of intermediate human capital during the French industrialization process

\section{Claude Diebolt, Charlotte Le Chapelain,}

Audrey Rose Menard 


\title{
Neither the elite, nor the mass. The rise of intermediate human capital during the French industrialization process
}

\author{
Claude Diebolt, Charlotte Le Chapelain, Audrey Rose Menard ${ }^{1}$
}

\begin{abstract}
This paper investigates the development of intermediate human capital in nineteenth century France. We perform panel and cross-section regression analyses to compare the effect of technological change on basic vs. intermediate human capital accumulation. Our contribution reveals that a shift in the kind of skills required occurred in the second half of the nineteenth century. We show that steam technology adoption was conducive to the accumulation of intermediate human capital in the second half of the nineteenth century.
\end{abstract}

Keywords: Cliometrics, Human Capital, Industrialization, France.

JEL Codes: N13, N33, N73, N93.

\section{Introduction}

The relationship between technological change and human capital is ambiguous. In the contemporary period, a consensus surrounds the idea that technological change is skill-biased and that it favors skilled labor over unskilled labor. Paradoxically, the industrialization process of the XVIII $-\mathrm{XIX} \mathrm{X}^{\text {th }}$ centuries is usually regarded as a deskilling process. The view that has prevailed until very recently is that, during the first stage of industrialization, technological advances increased relative demand for unskilled labor and therefore that technological innovation and skills were not complementary (see, for instance, Nicholas and Nicholas 1992, Mokyr 1993, Mitch 1999). According to Goldin and Katz (1998), the complementarity took place in the early $X X^{\text {th }}$ century with the technological shift from steam power to electricity.

\footnotetext{
${ }^{1}$ Diebolt: Bureau d'Economie Théorique et Appliquée, Université de Strasbourg. Address: 61 avenue de la Forêt Noire, 67085 Strasbourg Cedex, E-mail: cdiebolt@unistra.fr. Le Chapelain: Centre Lyonnais des Historiens du Droit et de la Pensée Politique, Bureau d’Economie Théorique et Appliquée, Université de Lyon 3. Address: 6 cours Albert-Thomas, 69355 Lyon Cedex 08, E-mail: charlotte.le-chapelain@univ-lyon3.fr. Menard: Laboratoire d'Economie et de Management Nord-Atlantique. Address: Chemin de la Censive du Tertre, 44000 Nantes, Email: audrey.menard@univ-nantes.fr.

We wish to thank Joerg Baten, Joyce Burnette, Alexandra De Pleijt, Chris Minns, Kevin O'Rourke, Alessandro Nuvolari, Douglas Puffert, Claudia Rei, Jacob Weisdorf and Jeffrey Williamson for helpful comments and discussions during the $8^{\text {th }}$ World Congress of Cliometrics. We are also grateful to Robin Cowan, David Le Bris, Julien Pénin, the audience of the Cournot Seminar and the participants at the "Cliometrics" session during the $66^{\text {th }}$ AFSE Congress. We are deeply indebted to the University of Lyon III, the University of Strasbourg (BETA), the Association De Dietrich and the Association Française de Cliométrie for their financial and scientific support.
} 
The view that the process of industrialization - during the age of steam power - was deskilling has recently prompted renewed attention and gives rise to contrasting results. Feldman and Van der Beek (2016) claim that technological progress was conducive to skills acquisition in eighteenth century England by showing that the number of apprentices and their share in the cohort of the fifteen-yearolds increased in response to inventions. Franck and Galor's (2017) analysis also supports the 'skillbiased technological change' hypothesis for the French case in the early nineteenth century (18391847). Using data on the share of workers employed in manufacturing as a yardstick for industrialization, Katz (2016) highlights a positive effect of industrialization on literacy rates (and on fertility) in the United-States during the period 1850-1900. For De Pleijt, Nuvolari and Weisdorf (2016), the effect of industrialization on human capital is mixed. They show that technological adoption was skill demanding since it improved the average skills of workers. However, they also evidence that adopting new technologies was not conducive to elementary education (approximated by literacy rates and enrolment rates). Contrastingly, De Pleijt and Weisdorf (2017) demonstrate a large decrease in average skills in agriculture and industry from the late sixteenth century to the early nineteenth century in England. They claim that deskilling globally occurred with technological progress, despite a modest increase in the share of 'high-quality' workers. This finding lends support to the view, already defended by Mokyr $(1990,2005)$ and, more recently for the French case, by Squicciarini and Voigtländer (2015), that upper-tail knowledge played a prominent role in early industrialization.

Our paper contributes to this open debate by focusing on a specific form of human capital intermediate human capital - which has not yet been investigated with regards to its link with the industrialization process. We provide analysis of the effects of steam technology adoption in the French industries on intermediate human capital accumulation throughout the nineteenth century (1839-1900).

Our approach builds on Mokyr's injunction to consider that human capital does not comprise one component and that it can blend very different types of skills, not all equivalently significant ('useful') whenever this concerns economic development: "Clearly human capital as a concept is indispensable, but we need to be far more specific as to what kind of human capital was produced, for and by whom, what was the source of the demand for it, and how it was distributed over the population." (Mokyr 2005, 1155).

The idea that there exist different forms of human capital and that they have different impacts regarding the process of industrialization is now very much taken into account. This has led to qualifying the dominant view that human capital played a minor role in the industrialization process, at least in its first phase. On the basis that Britain experienced low and stagnant level of education at the time of its industrial take-off, Mitch (1999) was one of the first to assert that differences in human 
capital endowments do not provide a convincing explanation of the industrialization process. This view has been confirmed by a number of scholars (see, for instance, Allen 2003, Clark 2005, Mc Closkey 2010, Mokyr 2005, Sandberg 1979). However, these studies mainly consider differences in basic knowledge, namely differences in literacy without considering the other forms of accumulated skills.

Other forms of human capital have recently been investigated. De La Croix et al. (2016) stress the important role of apprenticeship institutions for pre-industrial growth. The British system of apprenticeship is now regarded as a decisive explanatory dimension behind early industrialization in Britain (see Humphries (2003), Kelly, Mokyr and O'Grada (2014), Zeev, Mokyr and Van Der Beek (2017). Meisenzahl and Mokyr (2012) outline the decisive role of upper-tail knowledge in the British industrialization process. Differentiating between average and upper-tail skills, Squicciarini and Voigtländer (2015) provide evidence that human capital endowment of the elites in the XVIII ${ }^{\text {th }}$ century played a significant role in the French industrial take-off, contrary to average human capital.

Our approach builds upon the idea of 'useful knowledge' and of the disaggregation of the human capital variable in order to examine the effect of technological change on skills accumulation. We focus on a specific form of human capital - intermediate human capital - accumulated in nineteenth century France. This form of human capital has not yet been investigated, whereas it developed in close linkage with the needs of French industry by providing basic technical and scientific knowledge. In our analysis of the 'deskilling hypothesis', we therefore distinguish between basic human capital, which is characterized by basic literacy skills and intermediate human capital, which began to develop in the early XIX ${ }^{\text {th }}$ century, so as to examine changes in skills demand at the different stages of the technological change process.

Intermediate human capital refers to intermediate skills formed by the diffusion of basic general knowledge that goes beyond basic literacy and numeracy skills. Basic scientific and technical knowledge (linear drawing, geometry and mechanics, chemistry and physics, mathematics, marine and hydrography), foreign languages and basic knowledge in law and trade (accounting) make up this form of human capital. This is different from specific vocational skills provided by vocational schools and apprenticeship since intermediate human capital is general knowledge not directly intended to prepare to any specific occupation. It also differs from top scientific skills linked to any intellectual elite. Such extensive general knowledge spread in nineteenth century France by educational courses designed to be a kind of continuation of elementary school. These paths of education were mainly of two types: 'Ecoles Primaires Supérieures' (EPS henceforth) and Cours d'adultes et d'apprentis. ${ }^{2}$ Although they were intended for different audiences - pupils of 12-16 years old in the case of EPS and workers and employees for Cours d'adultes-their common purpose was to enhance the general level

\footnotetext{
${ }^{2}$ On the relationship between steam technology and the rise of adult education, see Diebolt, Le Chapelain and Ménard (2018).
} 
of skills in the population, and more precisely to foster the acquisition of technical and scientific knowledge.

We develop a panel data approach in order to study the effect of the number of steam engines in use in French counties upon the accumulation of intermediate human capital, measured by enrolments in EPS and Cours d'adultes. Our results show that technological change was conducive to the accumulation of this specific intermediate human capital. This effect has become more substantial as industrialization progressed. Furthermore, we implement cross-sectional analysis so as to compare the effects of technological adoption on basic human capital vs. intermediate human capital. Hence, we employ two sets of proxies, a set to measure the accumulation of basic literacy skills and a set to measure the formation of intermediate skills. We consider three time-spans (1839, 1861 and 1886) corresponding respectively to the first and second stages of the industrial revolution and to the period recognized as the second industrial revolution. ${ }^{3}$

Our results, for the early phase of industrialization, are consistent with those of Galor and Franck (2018) who claim that the first phase of the French industrialization process was not a deskilling process. In addition, our study shows that deskilling did not arise from the subsequent phases of the process but that there occurred a shift in the type of the skills demanded. We emphasize the fact that the adoption of the nineteenth century's 'General Purpose Technology' (see Rosenberg and Trajtenberg 2004) was conducive to the accumulation of basic human capital (literacy) at the first stage of the process but also during subsequent stages, and even more so during the second industrial revolution with the demand for enhanced skills. Indeed, the latter stage of the French industrialization process triggered intermediate human capital accumulation.

The paper is organized as follows. Section 2 provides a historical sketch of the development of intermediate human capital in nineteenth century France, shedding light on the new paths intermediate education which developed at that time. We describe our data in Section 3, the empirical strategy and results in Section 4 and Section 5 concludes.

\section{The rise and development of intermediate human capital}

Throughout the nineteenth century, France enjoyed great progress in literacy rates. By the end of the century, mass literacy was achieved. As shown in Diebolt et al. (2005), literacy skills were spread

\footnotetext{
${ }^{3}$ At this period, steam power remained the main source of energy for production. The first International Electricity Exhibition took place in Paris in 1881, but the use of electricity power in manufacturing was scarce (if null). According to David (1990, 356): "At the turn of the century, farsighted engineers had envisaged profound transformations that electrification would bring to factories stores, and homes. But the materialization of such visions hardly was imminent."
} 
among the French population well before the famous Ferry laws passed in 1881 and 1882. Furet and Ozouf (1977) have also analyzed the substantial progress made in literacy as a consequence of the dramatic expansion of the primary education system since the July Monarchy.

Alongside the accumulation of this basic human capital, another form of skills, which received less attention, began to spread in early nineteenth century France. The movement for literacy was indeed accompanied by the rise of new educational paths, which fostered the accumulation of intermediate human capital by offering post-elementary education "for the people"

Secondary schools (Collèges and Lycées) already offered post-elementary education but, as just mentioned, they primarily focused on the humanities (classics) and, more important, they were intended for a social élite. ${ }^{4}$ As recalled by Grew and Harrigan $(1991,192)$, social stratification characterized the organization of the French education system during this period: "elementary and secondary schools had been thought of more as distinct responses to different needs than as the lower and higher levels of a single system". Post-elementary education for the working classes began to develop in the first half of the nineteenth century and spread with the development of two branches of education: the Enseignements Primaires Supérieurs provided in the Ecoles Primaires Supérieures (EPS) and the Cours d'adultes.

The Guizot law (1833) provided that EPS, as part of the primary education system, were set up in every town of over 6,000 inhabitants. Intended for pupils from the age of twelve to sixteen, these 'Collèges du Peuple' (see Briand and Chapoulie 1992) provided intermediate education for the growing middle-classes. This went beyond the teaching of basic literacy skills dispensed by elementary schools, and did not include the classics taught in secondary schools to the bourgeoisie. EPS teachings offered to the students a basic scientific and technical training (linear drawing, geometry and mechanics, chemistry and physics, mathematics, marine and hydrography), but also offered children to be trained on foreign languages and on fundamentals in law and trade (accounting). ${ }^{5}$

The development of the EPS was intended to fill a gap in the French educational landscape: providing training for future skilled workers, commercial employees, industry and trade middle managers (see Briand and Chapoulie 1992) who claim for extended education but to whom secondary education, which was reserved to a social and intellectual elite, was not dedicated.

\footnotetext{
${ }^{4}$ According to Grew and Harrigan (1991, 192), enrolments in secondary schools were only about 3 percent of the enrolments in primary schools in the 1870s.

5 "L'instruction primaire supérieure comprend nécessairement, en outre, les éléments de la géométrie et ses applications usuelles, spécialement le dessin linéaire et l'arpentage, des notions des sciences physiques et de I'histoire naturelle applicables aux usages de la vie, le chant, les éléments de l'histoire et de la géographie, et surtout de l'histoire et de la géographie de la France. » (Guizot Law 1833, Article 1)
} 
Intermediate human capital developed also through another channel, i.e., adult education. The number of classes for adults (and enrollments) grew substantially throughout the nineteenth century (Diebolt, Le Chapelain, Ménard 2018). Although in part meant to address illiteracy, these courses were first and foremost intended to provide extended (and more sophisticated) instruction to the workers and apprentices. This will be particularly the case since the second half of the nineteenth century, when illiteracy had already sharply declined. As reported by Grew and Harrigan $(1991,184)$, this second purpose was prominent: "Yet, even in 1876-77, less than 6 percent of the men and only about 8 percent of the women enrolled in adult courses were struggling with reading and writing. Even then the most popular course of study, for both men and women, had been history and geography, followed (for men) by geometry and surveying and then by bookkeeping and commercial arithmetic, which was second in popularity for women."

Adult courses were attached to primary education and were first organized under the Guizot law (1833). The law did not make the creation of classes for adults compulsory, but supervised their development which resulted from public initiatives (teachers from public elementary schools) or private initiatives, be they from professional, scientific, philanthropic or religious organizations or associations. The kind of knowledge taught in the classes for adults was very close to that taught in the EPS. ${ }^{6}$ Some adult courses were taught, like the Enseignements Primaires supérieurs, by teachers of primary schools (instituteurs). It was general education with a focus on application. In the Restauration period and during the July Monarchy, courses offered to adults covered various fields such as linear drawing, geometry and mechanics, chemistry and physics, mathematics, law and legislation, trade, marine and hydrography, industrial courses for workers and blended courses. Just like the upperelementary education provided in the EPS, the adult education of workers and employees permitted the acquisition of scientific and technical knowledge and provided qualifications as complements to those acquired within the context of learning by doing (Christen 2014, Christen and Besse 2017).

Adults courses as well as EPS thus offered to the masses the possibility of continuing their instruction. They bridge the existing gap between primary education - whose role was limited to the diffusion of reading, writing and numeracy skills - and secondary education which focused on humanities - and eventually prepared a small fraction of children for higher education. Diffusing basic scientific and technical knowledge to the growing industrial and middle classes, they contributed to the accumulation of intermediate human capital.

\footnotetext{
"Rather different ambitions were met in adult courses designed for graduates of primary school who wanted to extend their education in courses that offered occupational or apprenticeship training or presented material rather like that provided in the école primaire supérieure." (Grew and Harrigan 1991: 182).
} 
Intermediate human capital thus took various forms and its accumulation resulted from distinct initiatives. It nevertheless can be circumscribed by three fundamental characteristics. First, it differs from basic human capital, which relates to basic literacy and numeracy skills diffused through elementary schools and also distinguishes itself from upper-tail human capital. Second, intermediate instruction is general education, which is not aimed at preparing to a specific occupation. This feature distinguishes intermediate education from vocational one and from apprenticeship. The final - and perhaps most important - fact is that intermediate education was intended to the growing industrial and middle classes who aspire, for their children or themselves, to be trained to knowledge that goes beyond basic literacy and numeracy skills but for whom elitist tracks of education (secondary education mostly), being reserved to a social and intellectual elite, were out of range.

\section{Data}

Was the adoption of the steam technology a driver of the development of intermediate human capital? And if so, how did the industrialization process affect the accumulation of this intermediate human capital in comparison to basic human capital?

To answer these questions, we consider the number of steam engines used in each county between 1839 and 1900 as a proxy for technological change. We also implement various proxies depicting basic and intermediate human capital accumulation.

\section{Steam Engines}

The use of steam power in France was regulated the legislative level by the ordinances of 2 April 1823, 29 October 1823, 7 May 1828, 25 May 1828, 23 September 1829, and 25 March 1830. The installation of steam engine in factories (ordinances of 23 September 1829 and 25 March 1830) was conditional to prefectoral authorizations. Supervisory responsibilities were assigned to the French mining engineers (Ingénieurs des Mines) who were responsible for guaranteeing the safe use of this new power source. Thus, all steam engines installed in French industries were first checked by engineers. Engineers reported information, by county, about their number in the Compte rendu des travaux des ingénieurs des mines (Direction générale des Ponts et Chaussées et des Mines) first, and then, from 1838 onwards, in the Statistique de l'industrie minérale et des appareils à vapeur.

Using statistical information contained in these two historical sources, we have built a new comprehensive dataset on the adoption of steam engines in French counties throughout the nineteenth century. Whereas quantitative evaluation of steam power in use in nineteenth century 
French industries generally draw upon sporadic statistical information contained in the industrial censuses (1839-1847, 1860-1865 and 1896), our dataset provides an exhaustive yearly assessment, from 1839 to 1909, of the diffusion of steam technology in France at the county level. It gathers information on the number of steam engines used in industries, the number of steam appliances, the number of industries in each French county that uses steam technology, and the steam power in use (horsepower). In line with Nuvolari, Verspagen and Von Tunzelmann (2011), our empirical analysis draws upon the number of steam engines to approximate regional heterogeneity in the adoption of steam technology. ${ }^{7}$ Figure 1 shows the spread of our data availability for France from 1839 to 1900. Figure 2 depicts the geographical diffusion of steam technology from 1839 to 1900.

Figure 1: Number of steam engines used in France from 1839 to 1900 (in thousands)

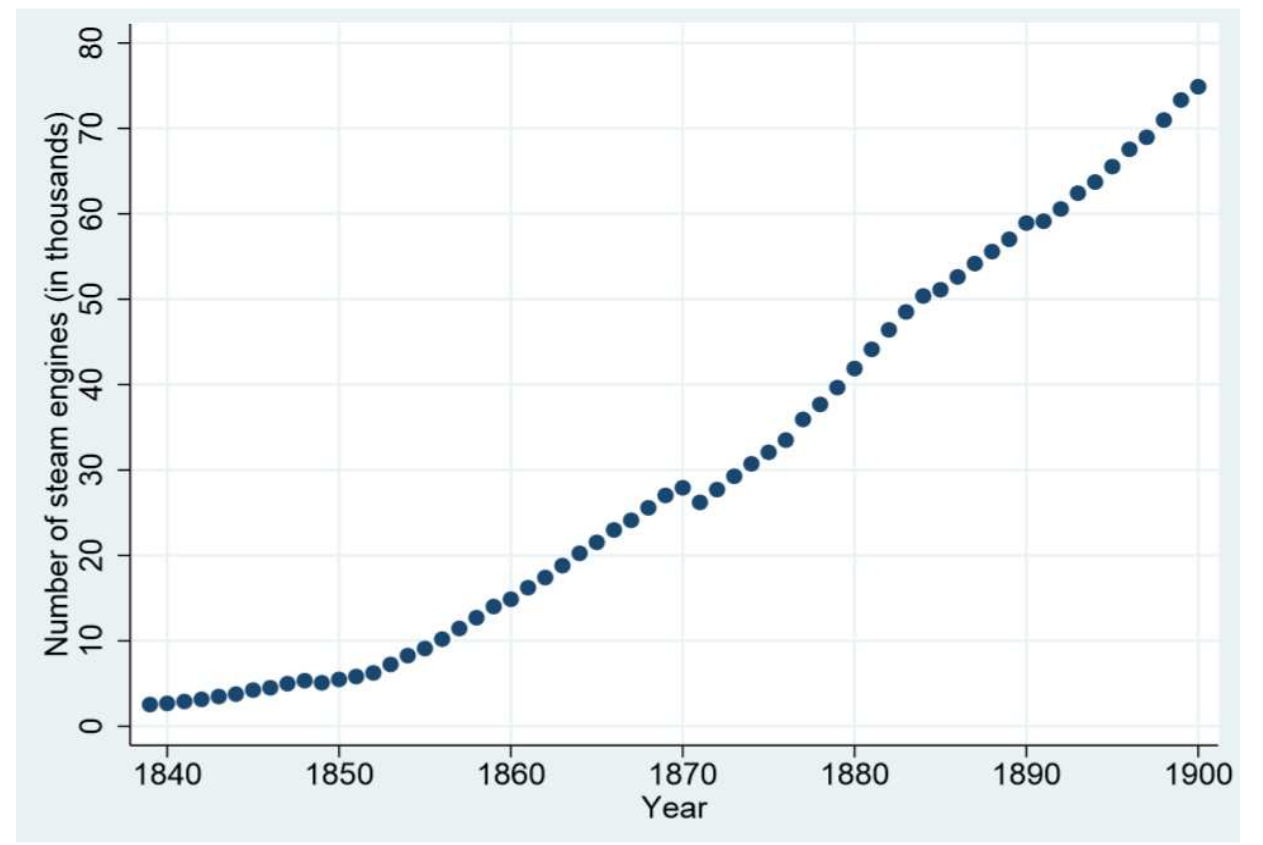

Figure 2. Number of steam engines in use in French industries

\footnotetext{
${ }^{7}$ Figure A.1 in Appendix A shows that the number of steam engines is highly correlated with the number of steam appliances, the number of industries in each French county that uses steam technology and the steam power in use.
} 


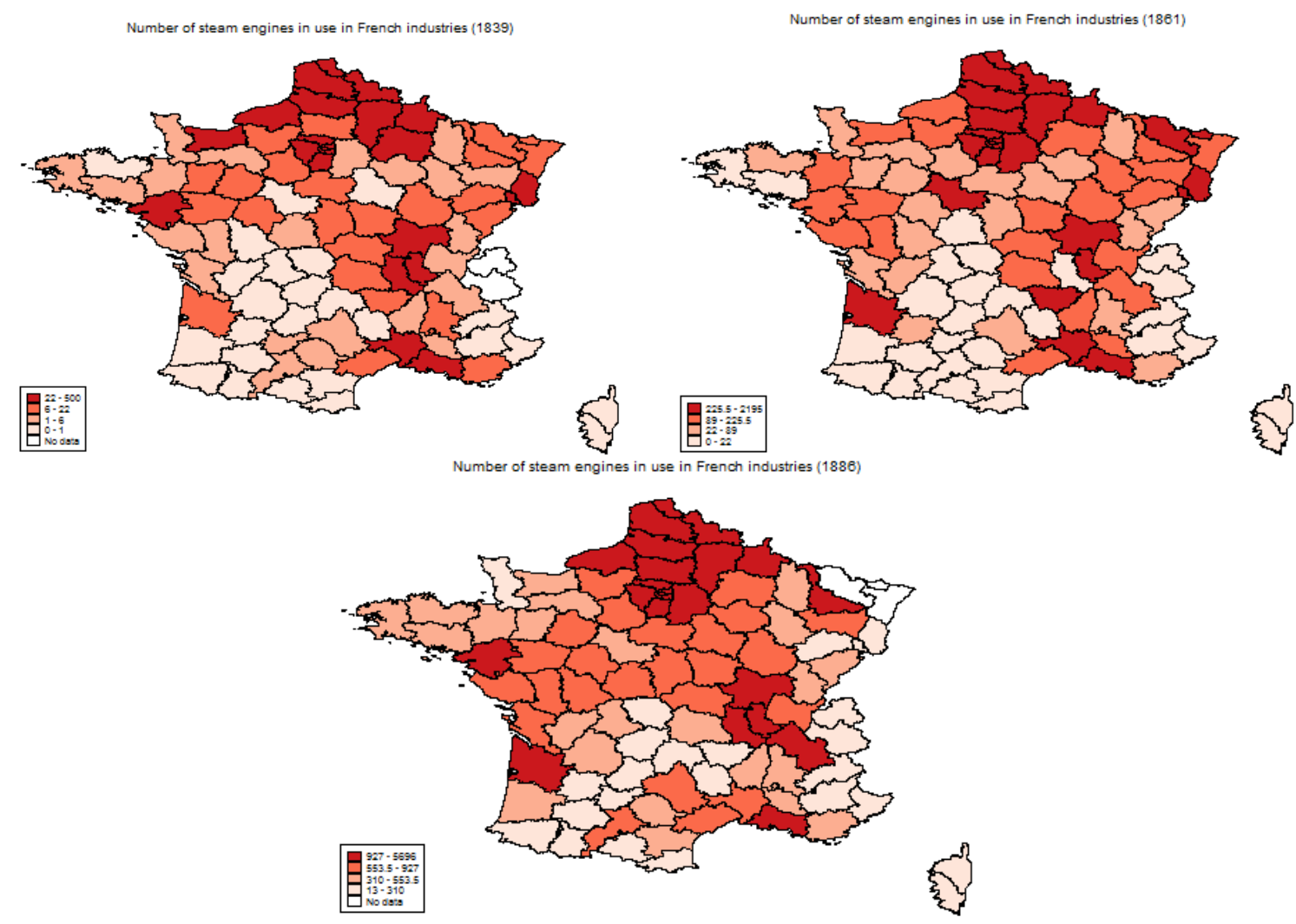

Data show a fast increase in steam engine usage since the beginning of the nineteenth century but also depict strong and persistent heterogeneity among the French counties. In 1839, 500 steam engines were in use in the Nord county whereas 16 counties had no machine at all. ${ }^{8}$ Close behind the Nord, the Seine operated 413 machines. The following counties were the Seine-Inférieure (260 machines), the Loire (256), the Rhône (96), the Haut-Rhin (86), and the Saône-et-Loire (86). At that time, 26 counties recorded one to five machines. In 1861, only seven counties recorded 1 to 5 machines but two counties still had no steam engine at all (Hautes-Alpes and Ariège). The Nord maintained its leading position with 2195 machines. Seine also remained in second place (2001 machines). At the same time, two counties located in the North of France (Pas-de-Calais and Aisne) accelerated their adoption of the steam engine. In 1886, the number of machines in use in the county of Seine exceeded the number of machines in the Nord.

\section{Human Capital}

We explore the effect of steam technology adoption on the accumulation of intermediate human capital first and investigate then its impact on basic human capital. Our proxies for human capital are derived from the Statistique Générale de la France.

\footnotetext{
${ }_{8}^{8}$ Basses-Alpes, Hautes-Alpes, Ariège, Cantal, Corrèze, Corse, Creuse, Landes, Lot, Lot-et-Garonne, Lozère, BassesPyrénées, Hautes-Pyrénées, Pyrénées-Orientales, Haute-Vienne and Yonne.
} 
Figure 3: Enrollments in adult courses and EPS
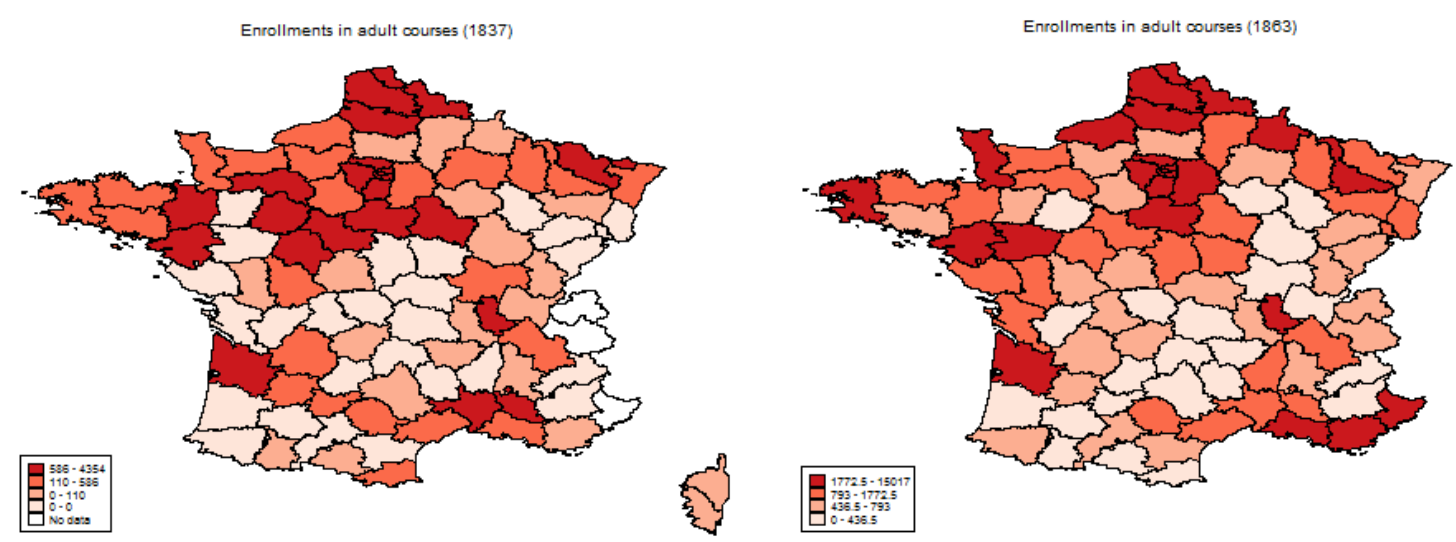

3

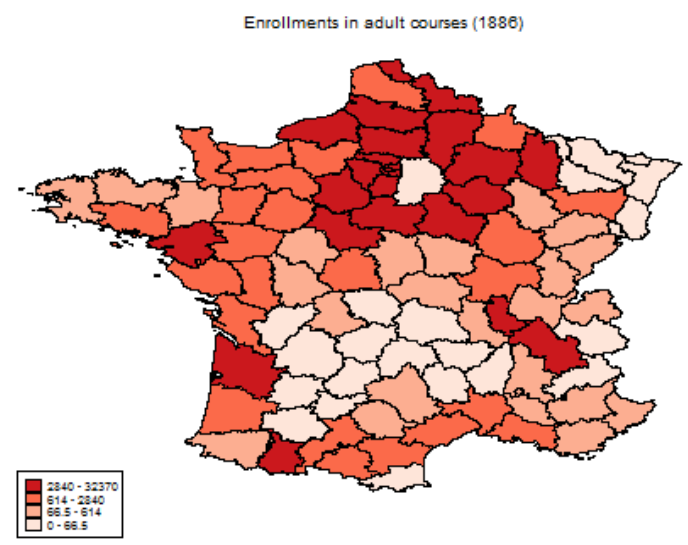

(3)
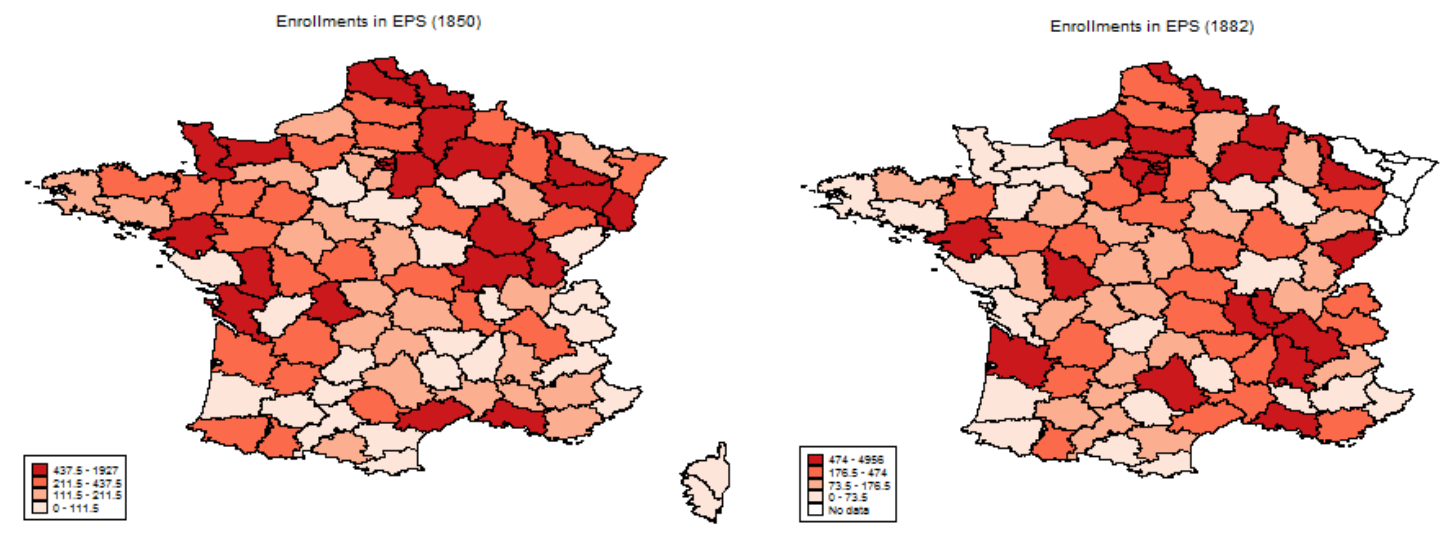

8 


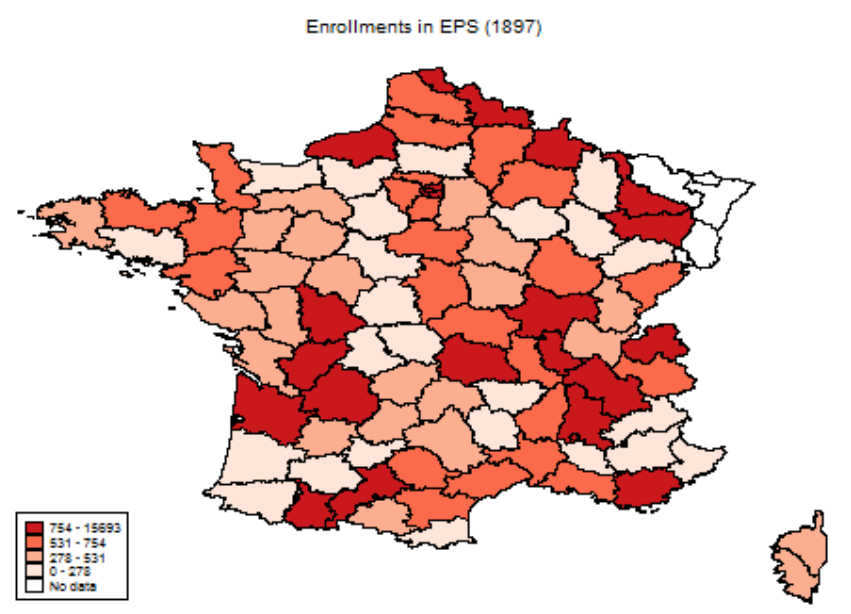

Intermediate human capital refers, as previously illustrated, to general knowledge that goes beyond basic literacy skills but that was neither vocational nor top scientific knowledge of the elite. In nineteenth century France, this spread through two main channels: the Ecoles Primaires Supérieures (EPS) and the Classes for adults. We consider enrollments in these two educational paths as indicators for the accumulation of intermediate human capital. We use the number of pupils enrolled in upper elementary schools ("EPS") and the number of men and women enrolled in adult classes per county. As depicted in Figure 3, regional variations in enrollments in either EPS or adult courses are particularly important.

We also draw comparison with the impact of steam technology adoption of the accumulation on basic human capital. Basic human capital refers to literacy skills. Here we use these three indicators: (i) the literacy rate, (ii) the number of primary schools per 10000 inhabitants and (iii) the number of towns with no school. Literacy rate is our direct measure for basic literacy skills. We approximate this by the proportion of army conscripts who were at least capable of reading. We deepen our evaluation of the heterogeneity in basic human capital endowments among the French counties with the other two indicators used as proxies for education supply. We rely on the number of primary schools per 10,000 inhabitants given that primary schools diffused primarily basic literacy skills. Alternatively, we use the number of municipalities in each county that have no school at all. These two proxies depict the density of the French education network at the county level. They provide information on differences in basic human capital accumulation since a county with a sparse educational network is prone to performing less well in terms of literacy than a county where the density of the education supply is higher. 
Confounding variables (from the Statistique Générale de la France)

Turning to our set of control variables, we account for specific regional variations that could have been decisive in explaining both industrialization and human capital formation, namely for the geographic county characteristics and for pre-industrial development indicators. We employ the number of royal roads in 1824 to reflect, for each county, the extension of infrastructure investments that favored the diffusion of industrialization. Our research also accounts for the population density recorded in 1801, as a proxy for pre-industrial urbanization. The process of urbanization can be associated with preindustrial development, because a growing population allows for specialization, which in turn can spur industrial growth and a learning technology. In addition, more urbanized counties were more prone to developing human capital. To measure pre-industrial human capital stocks, we use the proportion of Frenchmen who signed their marriage licenses in 1686-1690. We argue that the intensity in the use of the steam engine and human capital formation during the industrial era may have been favored by the pre-existence of such human capital stocks.

We capture the geographical differences between French counties with the following indicators. First, we use the share of cultivable land and the number of squared kilometers of fertile soil to measure land quality. Land quality may have influenced the adoption of steam engines and the development of schooling. In particular, landowners may have less interest in public schooling due to low complementarity between land and human capital (as argued in Galor, Moav and Vollrath 2009). Secondly, we include a dummy to account for counties having a maritime border, say access to sea and foreign contacts. Such connections may have enhanced the adoption of steam technology as well as human capital formation. Thirdly, we control for the latitude of each county, measured in the location of the county administrative centers and to also capture the possible influence of climate change among counties.

Finally, our regression analysis includes the aerial distance from Paris to each county administrative center. The Seine is an industrial area and pools the political institutions that might have more influence on industry and human capital formation in closer counties.

\section{Methodology and Results}

\section{Baseline results}

To investigate the relationship between the steam technology adoption and the accumulation of different types of human capital, we estimate the following equation:

$$
H_{i t}=\alpha+\beta \text { Steam_engine }{ }_{i t}+X_{i}^{\prime} \gamma+\varepsilon_{i t},
$$


where $H_{i t}$ is the log of our human capital variable of county $i$ in year $t$, Steam_engine $i t$ is the log of the number of steam engines of county $i$ in year $t, X_{i}^{\prime}$ is a vector of control variables that includes diverse time-invariant characteristics of county $i$; and $\varepsilon_{i t}$ is the error term of county $i$ in year $t$. The standard errors are robust to heteroskedasticity.

Panel analysis: the effect technological change on intermediate human capital EPS

We make use of panel data to assess the effect of the steam technology adoption on the development on various forms of human capital.

We start by applying an OLS estimator to investigate the relationship between the number of steam engines in use in French industries from 1839 to 1900 and enrollments in upper elementary education (EPS). The estimates are based on data available at seven points, i.e., 1840, 1850, 1882, 1886, 1891, 1897 and 1900. Firstly, we run a univariate analysis, regressing our measure of intermediate human capital on the steam technological adoption (see Column 1 in Table 1). Univariate results show a positive and significant correlation between the number of steam engines in use at the county level and the number of people enrolled in EPS. The estimate indicates that a $1 \%$ increase in the number of steam machines installed in a county is on average associated with a $0.3 \%$ increase in EPS enrolments. Secondly, in order to mitigate the impact of confounding factors, we perform multivariate analyses. Adding controls reduces unobserved heterogeneity. Nevertheless, due to data restrictions for several counties, we end up with a constrained sample when all controls are included. We therefore successively add different sets of demographic, geographic and pre-development variables defined at the county level (see Columns 2 to 4 in Table 1). Column 5 in Table 1 reports estimates of Equation 1 when all these controls are included together. The association between the number of steam engines in use in industries and EPS remains significant in all the regressions. Not surprisingly, we also observe that more populated counties display higher enrollments in EPS. Conversely, there is no significant effect of any of our control on the development of EPS. In particular, the preexisting stock of human capital (proxied by the share of people able to sign their marriage license in 1686-90) does not explain the extent of EPS in nineteenth century France.

Thirdly, we make sure that county specific factors are not the source of the differential pattern of EPS across French counties. We report fixed effects estimates of Equation (1), absorbing then all timeinvariant characteristics at the county level that are not observable (see Column 6 in Table 1). After controlling for county fixed effects, the estimate remains highly significant and positive. The fixed effects results are also useful to address the following concerns. As initial conditions may matter, fixed effects control for the fact that counties initially highly endowed in human capital have limited opportunities to accumulate human capital. Similarly, it controls for the fact that counties with higher 
initial levels of human capital could be prone to accumulate new forms of human capital. Any initial human capital differences among counties are absorbed by county fixed effects. More generally after controlling for fixed effects, it is unlikely that unobserved constant overtime characteristics affect the relationship between the steam technology adoption and our measures of human capital.

\section{Adult courses}

We continue our panel investigation by considering our second path of education through which intermediate skills were accumulated in nineteenth century France, say adult courses. Table 3 reports the results when regressing the log number of steam engines on enrolments in adult classes. The estimates are based on data available at seven points, i.e., 1839, 1850, 1863, 1867, 1869, 1872, 1876 and 1881 .

We present univariate and multivariate OLS estimates as well as Fixed effects estimates (see Table 2, Columns 1 to 6 , respectively). Our findings highlight a positive and significant association, at the $1 \%$ level, between the number of steam engines used in industries and the development of classes for adults. This relationship remains significant and statistically unchanged after progressively controlling for the confounding effects of geography, demography and pre-industrial development. The estimates indicate that a $1 \%$ increase in the number of steam machines installed in a county is on average associated with almost a $1 \%$ increase in adult courses enrolments.

Cross-sectional analysis: technological change and basic vs. intermediate human capital We now turn to focus our analysis on different years, as the French industrialization process goes by. This will provide us with a picture of the industrialization-human capital relationship at different stages of the steam technological change. We therefore present cross-sectional results with a twofold objective: (i) we make use of available but sporadic human capital data at three time points (1839, 1861 and 1886) in order to compare the effects of industrialization on basic vs. intermediate human capital accumulation across different phases of the French process of industrialization: the initial stage of the process (1839), the expansion phase of the second Kondratieff cycle (1861), and the latter stage corresponding to the 'second' industrial revolution (1886); (ii) we put under scrutiny our hypothesis that intermediate human capital spread as a response to technological adoption more intensively in the second half of the nineteenth century.

Each time point chosen to investigate the different stages of industrialization allows us to consider specific human capital measures while controlling for the same set of variables. For 1839, 1861 and 1886, we use two sets of proxies for human capital, one for basic human capital, one for intermediate human capital, as described in Section 3. Specifically, we use literacy rates (employing the share of army conscripts who can at least read), the number of primary schools per 10, 000 inhabitants and the 
number of municipalities with no school in each county to depict the accumulation of basic human capital. For intermediate human capital, we consider enrolments in upper elementary education (EPS) and enrolments in classes for adults.

We describe the corresponding cross section estimates of Equation (1) in Tables 3, 4 and 5.

The cross-section regression analysis put into light a positive correlation between the French process of technological change and basic human capital accumulation, approximated through our measure of literacy - the share of conscripts able to read and write at least - and through the number of schools per 10,000 inhabitants. Nevertheless, as the steam adoption process goes by, the number of municipalities with no school does not decrease anymore with the extend of industrialization and the positive association with literacy drops in magnitude (see Columns (3) to (5) in Tables 3, 4 and 5).

Results reported in Columns (1) and (2), however, confirm an upward tendency for intermediate human capital. Our data show that the effect of industrialization on enrolments in EPS and enrolments in courses for adults, i.e., on the formation of intermediate human capital, increases in magnitude in the second and third stages of industrialization. Columns (1) and (2) in Table 5 reveal that a $1 \%$ increase in the number of steam engines in use in 1886 increases by $0.677 \%$ the number of pupils enrolled in EPS and by $1.501 \%$ the number of adults enrolled in adult classes, while this relationship was insignificant during the early stage of industrialization. Counties adopting more steam engines in 1839 did not solicit higher enrolments in the two educational paths spreading intermediate knowledge (see Table 3, Columns (1) and (2)). We would argue that these results suggest a shift in the type of the skills needed by the adoption of the steam technology. This process has borne a significant influence on the formation of intermediate human capital, specifically during the second half of the nineteenth century.

Turning to the control variables, only our measure of literacy in the end of the seventeenth century seems to influence the extend of basic human capital during the first two stages of industrialization.

\section{Robustness tests}

We now turn to present results using alternative estimation strategies, say IV-2SLS estimation, as a robustness check of our baseline results.

Assessing the causal relationship between industrialization and human capital implies controlling for possible (and presumable) endogeneity biases. The statistical relationship between industrialization and human capital formation can be driven by reverse causality, namely by the effect of human capital on the use of industrial technology (see, for instance, Tamura (2002)). Added to this, both variable of interest can provide a common determinant in explaining variations in industrialization and variations 
in human capital, while these two variables do not affect each other. A statistical relationship between industrialization and human capital accumulation could thus only reflect a third common variable.

Hence, and following the methodology of Franck and Galor (2017), we use exogenous county variations in the distribution of steam engines across France so as to analyze the causal relationship between technological change and human capital accumulation. We follow Franck and Galor's proposition to use the aerial distance of each county administrative center to Fresnes-sur-Escaut as an instrument for the number of steam engines recorded in each county. The intensity in the use of the steam engine was very heterogeneous across the French counties, whatever stage of industrialization, as shown in Figure B.1 (in Appendix B). We observe a negative correlation between the distance of each county to Fresnes-sur-Escaut and the number of steam engines in use during three different stages of the French process of industrialization (1839, 1861 and 1886). Steam engines were globally more common in counties close to the Nord than elsewhere, as for instance the Somme, the Aisne, the Marne, and the Pas-de Calais, except for industrial areas, including the Loire, the Seine, the SeineInférieure and the Loire-Inférieure.

The regional diffusion of the steam engine from the Fresnes-sur-Escaut starting point can be used to pinpoint the effect of local variations in the distribution of the steam engine on human capital accumulation. This instrument is time-invariant, while we dispose of annual data for the number of steam engines. But it has the advantage to be strongly exogenous and completes our benchmark analysis supported by the OLS and the FE estimators. Franck and Galor use the distance between each French county and Fresnes-sur-Escaut to instrument the use of the steam engine in 1839-1847. We extend this use to the whole process of industrialization in France showing that the regional diffusion continues to explain the adoption of new steam engines some decades after the 1840s.

In the first stage of our 2SLS analysis, the log of the number of steam engines in county $i$ in year $t$ $\left(\right.$ Steam_engine $\left._{i t}\right)$ is instrumented by the aerial distance in kilometres between the county i's administrative centre and Fresnes-sur-Escaut (Distance_to_Fresnes ${ }_{i}$ ):

$$
\text { Steam_engine }_{i t}=\delta_{1} \text { Distance_to_Fresnes }_{i}+X_{1, i}^{\prime} \delta_{2}+\mu_{i t},
$$

where $X_{i}^{\prime}$ is the vector of control variables and $\mu_{i t}$ is the error term. $X_{i}^{\prime}$ includes geographical controls (cultivable land, fertile soil, latitude, maritime border, and distance to Paris) and pre-industrial development indicators (population density in 1801, the size of population in 1789, and the proportion of Frenchmen who could sign their marriage license in 1686-1690) in order to reduce unobserved heterogeneity. Specific county characteristics that may have contributed to the diffusion of the steam engine are therefore included in Equation 2. The standard errors are robust to heteroskedasticity to control for the possibility of heteroskedasticity. 
Table 6 reports panel and cross section estimates of Equation (2) using all controls. We first exploit the large panel dimension of the data to measure the strength of our instrument for the use of the steam engine, namely the distance of each county administrative center to Fresnes-sur-Escaut. We do so across the whole-time period during which France experienced steam technological change (18391900). Our estimates strengthen the finding described by Frank and Galor (2017). Not only is the relationship negative and strongly significant in the early stage of industrialization, but the relationship holds during all the French industrialization process. We also note that no covariate affects the negative association between the distance from Fresnes-sur-Escaut and the number of steam engines. The relationship remains robust across all specifications.

In Table 7, we show that the distance of each county administrative center to Fresnes-sur-Escaut is orthogonal to several measures of pre-economic and educational development, i.e., not related to possible significant pre-existing correlates of industrialization.

We first implement panel analyses to examine the effect of technological adoption on the accumulation of intermediate human capital for the 1839-1900 period. Tables 8.a and 8.b display the 2SLS estimates.

We start by considering the effect of industrialization on the number of pupils enrolled in EPS. Our findings highlight a positive and significant association, at least at the $5 \%$ level, of the number of steam engines used in industries and enrolments in this path of education. This relationship remains significant after controlling for the confounding effects of geography, demography and pre-industrial development. In particular, the estimate indicates that a $1 \%$ increase in the number of steam machines installed in a county is on average associated with a $0.593 \%$ increase in EPS enrolments.

We now turn to the analysis of the second path of education through which intermediate skills were accumulated in nineteenth century France. Table 8.a report the IV estimates of Equation (1), regressing the log number of steam engines on enrolments in adult classes and employing the whole available panel dataset. When all the time-invariant covariates presented in the data section are included into the regression, the significance dwindles. We expect that the effect of technological change on intermediate human capital accumulation strengthened as industrialization unfolded, as suggested by the baseline results. We run additional panel regressions excluding the first industrialization period (years prior to 1850 and then prior to 1863). When we focus on the second half of the nineteenth century (see Table 8.b), we find evidence of a positive influence of the steam technological adoption and enrolment in adult classes. From 1863 onward, a 1\% increase in the number of steam machines installed in a French county is associated on average with a $0.402 \%$ increase in enrolments in adult classes. 
We now take benefit from our cross-sectional analyses to evidence a shift in the type of skills required. Tables 9 to 11 report the cross-section results for the three time points (1839, 1861 and 1886, respectively). Columns (1) to (3) show the IV results for basic human capital and Columns (4) and (5) for intermediate human capital. The first phase of the French industrialization process has been conducive to the accumulation of basic skills. Our results reveal that, for the first two periods, more steam engines in use is significantly associated with higher literacy rates and with a denser educational network. ${ }^{9}$ In 1839, a $1 \%$ increase in the number of steam engines is significantly and positively associated with a $1.116 \%$ decrease in the number of municipalities with no school in the 1840s. In 1861, the magnitude decreases, but the relationship remains highly significant: a 1\% increase in the number of steam engines in 1861 decreased the number of municipalities with no school in 1863 by $0.631 \%$. This downward tendency is confirmed by the regression results for 1886 . In 1886 , the steam technology adoption no longer plays any significant role on the accumulation of basic skills. We would argue that technological change required basic human capital during the first stage of industrialization. On the other hand, as the adoption of the steam technology expended, basic skills became less required until they were not needed anymore. Was there consequently a shift in the type of skills required?

The data confirm the hypothesis of a change in the nature of the skills required. They show a positive and significant effect of industrialization on enrolments in EPS and enrolments in courses for adults, i.e., on the formation of intermediate human capital, during the second and third stages of industrialization. In particular, a 1\% increase in the number of steam engines in use in 1886 increases by $0.874 \%$ the number of pupils enrolled in upper-elementary education and by $1.100 \%$ the number of adults enrolled in adult classes. This relationship was insignificant during the early stage of industrialization. Counties adopting more steam engines in 1839 did not solicit higher enrolments in the two educational paths spreading intermediate knowledge. ${ }^{10}$ These cross-sectional analyses confirm our panel regressions conclusions: technological change started affecting the development of intermediate human capital at a later stage of industrialization, i.e., in the second half of the nineteenth century. We argue that these results suggest a shift in the type of the skills needed around this stage of industrialization.

To summarize, our IV estimates confirm the baseline results. Whether the number of steam engines in use in each county is instrumented or not, the data reveal that industrialization in the second half of the nineteenth century led to intermediate human capital accumulation, allowed by the creation of

\footnotetext{
${ }^{9}$ Due to the lack of available data, we use the number of primary schools per 10000 inhabitants and the number of municipalities with no school in 1837 as a proxy for the density of the educational network in the 1840s. We make the assumption that the educational network varied slowly. To check robustness, we test the number of municipalities with no school in 1850. Estimates are very similar.

${ }^{10}$ Due to data constraints, we consider enrolments in classes for adults in 1837 as a proxy for 1840 . The relationship remains non-significant when considering a 10 years lag.
} 
EPS courses and the development of lifelong learning. Thanks to our instrumentation strategy, a third common variable that influences both the adoption of the steam technology and the accumulation of human capital is not expected to explain the statistical association between both.

\section{Conclusion}

This contribution, by emphasizing the development of intermediate human capital in nineteenth century France, brings to light a shift in the type of skills accumulated in response to the steam technology adoption. We evidence that, in the first phase of the industrialization process, the positive effect of technological change on human capital formation concerned only basic skills but vanished in the second half of the century. Instead, in the second half of the century, intermediate human capital (and no more basic human capital) developed in response to technological change. This latter effect would have been hidden if we had not considered a disaggregated perspective of human capital. Our results state that basic human capital only cannot be used as a unique measure of the stock of human capital to investigate the relationship between human capital and industrialization in nineteenth century France.

How to explain this shift in the type of skills and knowledge required by technological change in the second half of the nineteenth century? Addressing this issue adequately would require fuller analysis that would fall beyond of the scope of this contribution. But two avenues may be explored. First, a wealth effect can plausibly be at the origin of the positive association between steam power use at the department level and human capital accumulation. Under the hypothesis that the counties that made a more intensive usage of the steam technology were more industrialized and richer, the county wealth might have favored the emergence of a richer industrial and middle class who called for a more comprehensive education. Investments in intermediate human capital could then result from the fact that changes in wealth modified middle classes' aspirations by raising new educational and cultural aspirations what fostered, in turn, the development of intermediate paths of education (EPS and adult education).

Second, changes in educational investment might also be linked to technological change per se and to the increasing complexity of steam technology. Private investment in intermediate education might have increased due to technological change because returns to intermediate schooling increased with technological progress. Under that hypothesis, intermediate human capital accumulation resulted from the fact that individuals invested in useful knowledge to face an increase in the complexity of the steam technology, the later technologies being more advanced and hence requiring more advanced levels of human capital. 
Bibliography

Allen, R. C. (2003). "Progress and poverty in early modern Europe”. Economic History Review, 56(3), 403-443.

Atack J., F. Bateman and T. Weiss (1980). The Regional Diffusion and Adoption of the Steam Engine in American Manufacturing. Journal of Economic History, 40(2), 281-308.

Briand, J. P. and J. M. Chapoulie (1992). Les collèges du peuple. L'enseignement primaire supérieur et le développement de la scolarisation prolongée sous la Troisième République. INRP/CNRS/ENS, Paris.

Christen, C. (2014). Jalons pour une histoire de l'éducation industrielle destinée aux ouvriers adultes au XIXe siècle. Les Études Sociales, (1), 3-9.

Christen, C., Besse, L. (dir.) (2017). Histoire de l'éducation populaire 1815-1945. Perspectives françaises et internationales, Villeneuve d'Ascq, Presses universitaires du Septentrion (Histoire et Civilisations).

Clark, G. (2005). The condition of the working class in England, 1209-2004. Journal of Political Economy, 113(6), 1307-1340.

David, P. A. (1990). The Dynamo and the Computer: an Historical Perspective on the Modern Productivity Paradox. American Economic Review, 80(2), 355-361.

Diebolt, C. (2016). Cliometrica after 10 Years. Definition and Principles of Cliometric Research. Cliometrica, 10(1), 1-4.

Diebolt, C., Jaoul, M., and San-martino, G. (2005). Le mythe de Ferry : une analyse cliométrique. Revue d'Economie Politique, 115(4), 471-497.

Diebolt, C., Le Chapelain, C. and Ménard, A. (2018). Learning outside the factory: the impact of technological change on the rise of adult education in nineteenth-century France". Working paper AFC 2-2018. Feldman, N. E. and van der Beek, K. (2016). Skill choice and skill complementarity in eighteenth century England. Explorations in Economic History, 59(January), 94-113.

Franck, R. and Galor, O. (2018). Technology-Skill Complementarity in the Early Phase of Industrialization. IZA Discussion Paper Series n9758.

Furet, F. and Ozouf, J. (1977). Lire et écrire : I'alphabétisation des Français de Calvin à Jules Ferry, Paris, Éditions de Minuit, 2 vols.

Galor, O., Moav, O. and Vollrath, D. (2009). Inequality in Landownership, the Emergence of HumanCapital Promoting Institutions, and the Great Divergence. Review of Economic Studies, 76(1), 143-179.

Goldin, C. and Katz, L.F. (1998). The Origins of Technology-skill Complementarity. Quarterly journal of economics, 113(3), 693-732.

Grew, R. and Harrigan, P. (1991). School, State, and Society: The Growth of Elementary Schooling in Nineteenth-Century France: A Quantitative Analysis. Ann Arbor, University of Michigan Press.

Humphries, J. (2003). "English Apprenticeship: A Neglected Factor in the First Industrial Revolution." In The Economic Future in Historical Perspective, edited by Paul A. David and Mark Thomas. Oxford University Press.Kelly, M., Mokyr, J., and Gráda, C. Ó. (2014), "Precocious Albion: a new interpretation of the British industrial revolution". Annu. Rev. Econ., 6(1), 363-389.

McCloskey, D. N. (2010). Bourgeois Dignity: Why Economics can't Explain the Modern World. Chicago, University of Chicago Press.

Mitch D. (1999). The Role of Education and Skill in the British Industrial Revolution in: J. Mokyr (ed.), The British Industrial Revolution: An Economic Perspective, 2nd edition, Boulder: Westview, 241-279.

Mokyr, J. (1990). The Lever of Riches: Technological Creativity and Technological Progress, Oxford, Oxford University Press.

Mokyr J. (1993). The New Economic History and the Industrial Revolution in J. Mokyr (Ed.), The British Industrial Revolution: An Economic Perspective, Boulder: Westview, Editor's Introduction. 
Mokyr, J. (2005). Long-Term Economic Growth and the History of Technology in: Aghion, P., \& Durlauf, S. (Eds.). Handbook of Economic Growth (Vol. 1). Elsevier, 1113-1180.

De La Croix, D., Doepke, M. and Mokyr, J. (2016). Clans, Guilds, and Markets: Apprenticeship Institutions and Growth in the Pre-Industrial Economy (No. w22131). National Bureau of Economic Research.

De Pleijt, A. M., Nuvolari, A. and Weisdorf, J. (2016). Human Capital Formation during the First Industrial Revolution: Evidence from the Use of Steam Engines (No. 294). Competitive Advantage in the Global Economy (CAGE).

De Pleijt, A. M. and Weisdorf, J. (2017). Human capital formation from occupations: the 'deskilling hypothesis' revisited. Cliometrica, 11(1), 1-30.

Meisenzahl, R. and Mokyr, J. (2012). "The Rate and Direction of Invention during the Industrial Revolution: Incentives and Institutions." In Josh Lerner and Scott Stern, eds. The Rate and Direction of Inventive Activity Revisited. Chicago: University of Chicago Press, pp. 443-79.

Nicholas, S. J. and Nicholas, J. M. (1992). Male Literacy, "Deskilling," and the Industrial Revolution. Journal of Interdisciplinary History, 23(1), 1-18.

Nuvolari, A. (2010). The Theory and Practice of Steam Engineering in Britain and France, 1800-1850. Documents pour l'histoire des techniques. Nouvelle série, 19, 189-197.

Nuvolari A. and B. Verspagen (2009). Technical Choice, Innovation and British Steam Engineering, 1800-1850. Economic History Review, 62(3), 685-710.

Nuvolari A., B. Verspagen and N. von Tunzelmann (2011). The Early Diffusion of the Steam Engine in Britain, 1700-1800: a Reappraisal. Cliometrica, 5(3), 291-321.

Kanefsky, J.W. (1979). The Diffusion of Power Technology in British industry. 1760-1870 (Doctoral dissertation, University of Exeter).

Kanefsky, J. and Robey, J. (1980). Steam Engines in 18th-Century Britain: A Quantitative Assessment. Technology and Culture, 21(2), 161-186.

Katz, O. (2016). The Effect of Industrialization on Fertility and Human Capital in the 19th Century: Evidence from the United States. Working paper.

Rosenberg, N. and Trajtenberg, M. (2004). A General-Purpose Technology at Work: The Corliss Steam Engine in the Late-Nineteenth-Century United States. Journal of Economic History, 64(1), 61-99.

Sandberg, L.G. (1979). The case of the impoverished sophisticate: human capital and Swedish economic growth before World War I. Journal of Economic History, 39(1), 225-241.

Squicciarini M. and Voigtländer N. (2015), Human Capital and Industrialization: Evidence from the Age of Enlightenment. Quarterly Journal of Economics, 30(4), 1825-83.

Tamura, R. (2002). Human Capital and the Switch from Agriculture to Industry. Journal of Economic Dynamics and Control, 27(2), 207-242.

Zeev, N. B., Mokyr, J., and Van Der Beek, K. (2017), "Flexible supply of apprenticeship in the british industrial revolution". The Journal of Economic History, 77(1), 208-250. 
Appendix A

Figure A.1: Number of steam engines in use in France (1839-1900), number of industries in France using the steam technology (1840-1900) and the steam power in use in France (1840-1900)

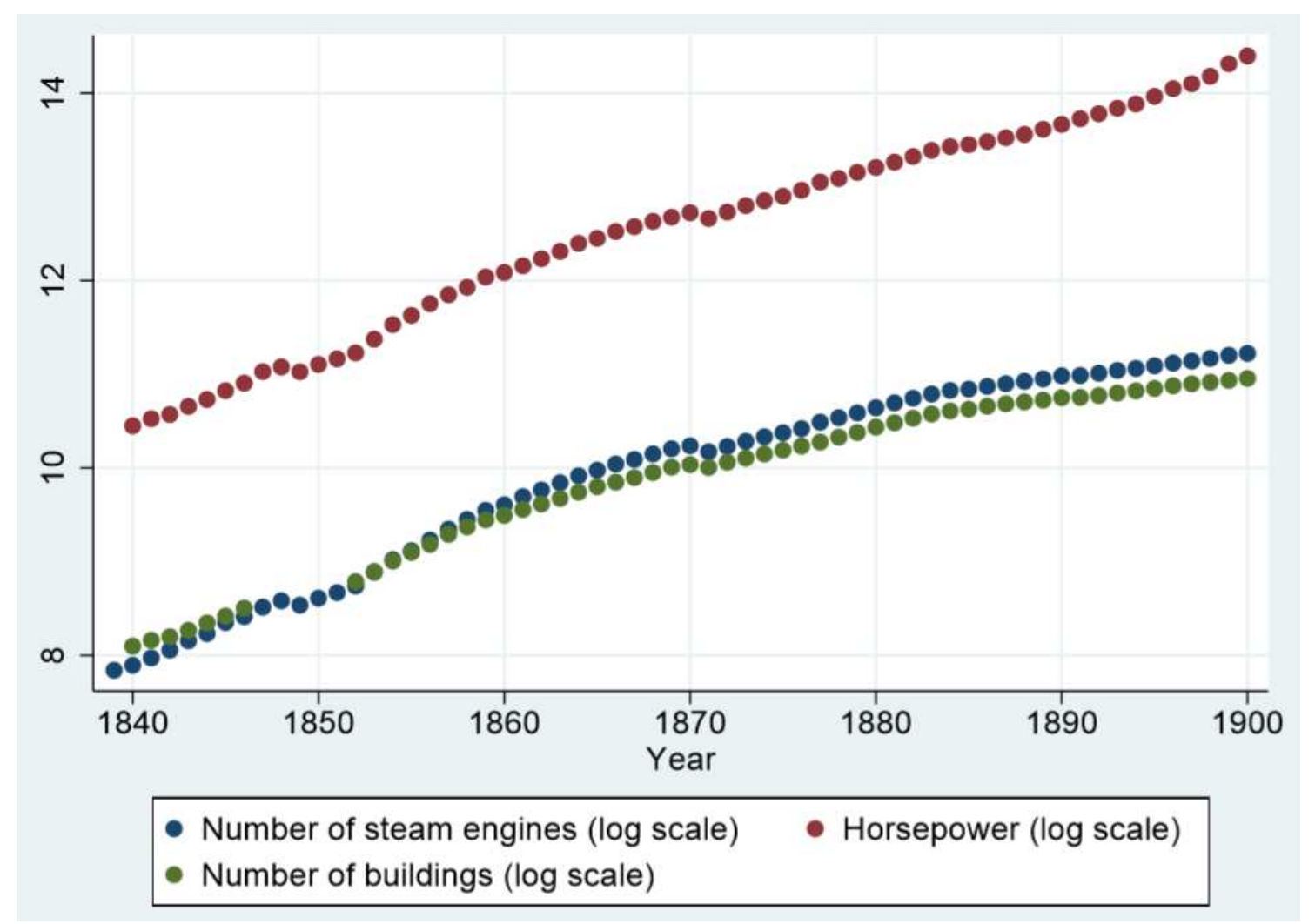




\section{Appendix B}

Figure B.1: Number of steam engines against distance to Fresnes, in 1839, 1861 and 1886: scatter plots and linear prediction
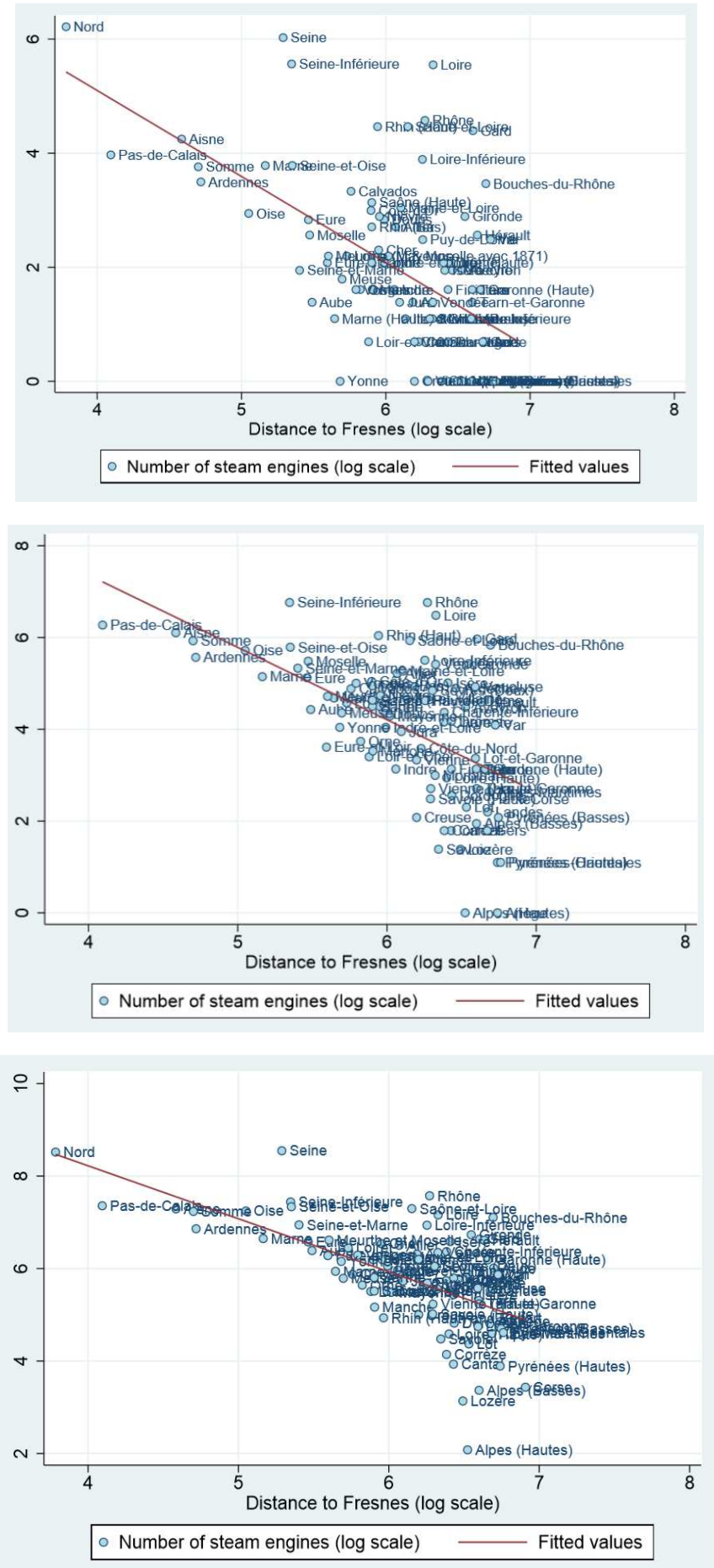
Appendix C: Summary statistics for cross sectional analyses

\begin{tabular}{|c|c|c|c|c|c|}
\hline Variable & Obs. & Mean & St. dev. & Min. & Max. \\
\hline \multicolumn{6}{|l|}{ Steam engines } \\
\hline Steam engines (number in 1839) & 87 & 29.21839 & 78.66923 & 0 & 500 \\
\hline Steam engines (number in 1861) & 89 & 177.5843 & 339.6053 & 0 & 2195 \\
\hline Steam engines (number in 1886) & 87 & 603.1149 & 818.2184 & 7 & 5156 \\
\hline \multicolumn{6}{|l|}{ Human capital } \\
\hline \multicolumn{6}{|l|}{1839} \\
\hline \multicolumn{6}{|l|}{ Basic skills } \\
\hline Schools per 10,000 inhabitants 1837 & 86 & 16.37105 & 6.576636 & 4.87 & 35.41 \\
\hline Number of Municipalities with no school in 1837 & 86 & 65.89535 & 58.81797 & 0 & 271 \\
\hline Proportion of conscripts in 1871-1875 & 86 & 65.74767 & 18.22843 & 26.1 & 96.3 \\
\hline \multicolumn{6}{|l|}{ Intermediate skills } \\
\hline Number of men in classes for adults in 1837 & 86 & 429.814 & 775.1765 & 0 & 4354 \\
\hline Number of men in EPS in 1840 & 89 & 171.4045 & 288.0978 & 0 & 2317 \\
\hline \multicolumn{6}{|l|}{1861} \\
\hline \multicolumn{6}{|l|}{ Basic skills } \\
\hline Number of municipalities with no school in 1863 & 89 & 9.191011 & 14.81697 & 0 & 94 \\
\hline Proportion of conscripts in 1851-1855 & 87 & 82.47241 & 11.13518 & 50.9 & 98.7 \\
\hline \multicolumn{6}{|l|}{ Intermediate skills } \\
\hline Number of individuals in EPS in 1882 & 86 & 348.0116 & 607.7334 & 0 & 4956 \\
\hline Number of individuals in classes for adults in 1863 & 89 & 1411.764 & 2178.488 & 0 & 15017 \\
\hline \multicolumn{6}{|l|}{1886} \\
\hline \multicolumn{6}{|l|}{ Basic skills } \\
\hline Schools per 10000 inhabitants in 1886 & 86 & 24.28488 & 8.632967 & 6.4 & 59.1 \\
\hline Number of municipalities with no school in 1886 & 85 & .9411765 & 1.966099 & 0 & 12 \\
\hline Proportion of conscripts in 1886 & 86 & 94.97674 & 4.243214 & 80.6 & 99.7 \\
\hline \multicolumn{6}{|l|}{ Intermediate skills } \\
\hline Number of individuals in classes for adults in 1886 & 89 & 2032.27 & 4082.784 & 0 & 32370 \\
\hline Number of individuals in EPS in 1886 & 86 & 445.6512 & 686.3865 & 0 & 5616 \\
\hline \multicolumn{6}{|l|}{ Instrument and Controls } \\
\hline Distance to Fresnes (aerial distance in $\mathrm{km}$ ) & 89 & 497.5562 & 220.6439 & 43 & 999.5 \\
\hline Distance to Paris (aerial distance in $\mathrm{km}$ ) & 89 & 365.4663 & 188.7642 & 0 & 918.86 \\
\hline $\begin{array}{l}\text { Literacy (percent of individuals who signed their marriage } \\
\text { license in 1686-1690) }\end{array}$ & 76 & 18.96816 & 10.87633 & 3.68 & 45.66 \\
\hline Latitude & 89 & 46.42664 & 2.105079 & 41.9192 & 50.6292 \\
\hline Fertile soil (in 1837) & 86 & 84608.93 & 100777.4 & 0 & 429000 \\
\hline Cultivable land (in 1834) & 86 & 215814.2 & 90405.15 & 29278 & 416770 \\
\hline Royal roads (number in 1824) & 86 & 6.953488 & 3.184178 & 3 & 25 \\
\hline Population density (in 1801) & 86 & 1314.895 & 2757.644 & 0 & 26316 \\
\hline Maritime & 89 & .258427 & .4402502 & 0 & 1 \\
\hline
\end{tabular}


Tables

Table 1. The effect of industrialization on enrollments in EPS

\begin{tabular}{|c|c|c|c|c|c|c|}
\hline & (1) & (2) & (3) & (4) & (5) & (6) \\
\hline & $\begin{array}{c}\text { Univariate } \\
\text { OLS } \\
\text { estimates }\end{array}$ & & Multivariates & OLS estimates & & $\begin{array}{c}\mathrm{FE} \\
\text { estimates }\end{array}$ \\
\hline \multirow[t]{2}{*}{ Number of steam engines } & $0.328^{* * *}$ & $0.323^{* * *}$ & $0.307^{* * *}$ & $0.304 * * *$ & $0.289 * * *$ & $0.299 * * *$ \\
\hline & (8.74) & (8.87) & $(8.20)$ & $(8.22)$ & (7.26) & (7.55) \\
\hline \multirow[t]{2}{*}{ Latitude } & & 0.819 & & & 0.687 & \\
\hline & & $(0.36)$ & & & $(0.25)$ & \\
\hline \multirow[t]{2}{*}{ Cultivable land (1834) } & & $-0.342 * *$ & & & 0.015 & \\
\hline & & $(-2.42)$ & & & $(0.08)$ & \\
\hline \multirow[t]{2}{*}{ Fertile soil (1837) } & & $0.053 * * *$ & & & 0.026 & \\
\hline & & $(2.68)$ & & & $(1.16)$ & \\
\hline \multirow[t]{2}{*}{ Maritime } & & 0.200 & & & -0.094 & \\
\hline & & $(0.88)$ & & & $(-0.34)$ & \\
\hline \multirow[t]{2}{*}{ Distance to Paris } & & $-0.183^{*}$ & & & 0.175 & \\
\hline & & $(-1.68)$ & & & (1.49) & \\
\hline \multirow[t]{2}{*}{ Density (1801) } & & & $0.000 * * *$ & & 0.000 & \\
\hline & & & (3.31) & & (0.54) & \\
\hline \multirow[t]{2}{*}{ Population (1789) } & & & $0.357^{* * *}$ & & $0.291^{* *}$ & \\
\hline & & & $(3.35)$ & & (2.17) & \\
\hline \multirow[t]{2}{*}{ Literacy (1686-1690) } & & & & 0.001 & 0.002 & \\
\hline & & & & $(0.23)$ & $(0.36)$ & \\
\hline \multirow[t]{2}{*}{ Constant } & $3.823 * * *$ & 5.373 & 0.187 & $3.932 * * *$ & -3.199 & $3.968 * * *$ \\
\hline & $(17.73)$ & $(0.64)$ & $(0.18)$ & (14.98) & $(-0.31)$ & $(20.02)$ \\
\hline Observations & 602 & 587 & 580 & 527 & 520 & 602 \\
\hline $\mathrm{R}^{2}$ & 0.2617 & 0.3057 & 0.3204 & 0.2547 & 0.2841 & 0.2617 \\
\hline
\end{tabular}

Note: All variables except the dummies and rates are in logarithm. The dependent variable is the enrollment in EPS (in log). Columns (1) to (5) report OLS estimates. Column (6) reports Fixed effect estimates. Column (2) reports estimates of Equation (1) when geographical controls are included. Column (3) reports estimates of Equation (1) when population controls are included. Column (4) reports estimates of Equation (1) when predevelopment controls are included. Column (5) reports estimates of Equation (1) when all controls are included. T-statistics are reported in brackets. ${ }^{* * *}$ indicates significance at the $1 \%$-level, ${ }^{* *}$ indicates significance at the $5 \%$-level, * indicates significance at the $10 \%$-level.

Table 2. The effect of industrialization on enrollments in adult courses

\begin{tabular}{cccccccc}
\hline \multicolumn{3}{c}{$(1)$} & $(2)$ & $(3)$ & $(4)$ & (5) & FE \\
\hline & $\begin{array}{c}\text { Univariate } \\
\text { OLS } \\
\text { Estimates }\end{array}$ & & Multivariates OLS Estimates & & estimates \\
\hline Number of steam engines & $1.045^{* * *}$ & $0.905^{* * *}$ & $0.921^{* * *}$ & $0.906^{* * *}$ & $0.946^{* * *}$ & $1.268^{* * *}$ \\
& $(17.18)$ & $(14.12)$ & $(16.33)$ & $(14.60)$ & $(14.61)$ & $(17.10)$
\end{tabular}




\begin{tabular}{|c|c|c|c|c|c|c|}
\hline \multirow[t]{2}{*}{ Latitude } & & \multicolumn{3}{|l|}{$-9.063^{* *}$} & \multicolumn{2}{|l|}{-6.725} \\
\hline & & \multicolumn{3}{|l|}{$(-2.37)$} & \multicolumn{2}{|l|}{$(-1.38)$} \\
\hline \multirow[t]{2}{*}{ Cultivable land (1834) } & & \multicolumn{3}{|l|}{0.211} & \multicolumn{2}{|l|}{0.046} \\
\hline & & \multicolumn{3}{|l|}{$(0.78)$} & \multicolumn{2}{|l|}{$(0.13)$} \\
\hline \multirow[t]{2}{*}{ Fertile soil (1837) } & & \multicolumn{3}{|l|}{-0.018} & \multicolumn{2}{|l|}{-0.010} \\
\hline & & \multicolumn{3}{|l|}{$(-0.60)$} & \multicolumn{2}{|l|}{$(-0.30)$} \\
\hline \multirow[t]{2}{*}{ Maritime } & & \multicolumn{3}{|l|}{0.472} & \multicolumn{2}{|l|}{$1.090 * * *$} \\
\hline & & \multicolumn{3}{|l|}{$(1.28)$} & \multicolumn{2}{|l|}{$(2.81)$} \\
\hline \multirow{2}{*}{$\begin{array}{l}\text { Distance to } \\
\text { Paris }\end{array}$} & & \multicolumn{3}{|l|}{-0.053} & \multicolumn{2}{|l|}{-0.146} \\
\hline & & \multicolumn{3}{|l|}{$(-0.39)$} & \multicolumn{2}{|l|}{$(-0.60)$} \\
\hline \multirow[t]{2}{*}{ Density (1801) } & & & \multicolumn{2}{|l|}{-0.000} & \multicolumn{2}{|l|}{-0.000} \\
\hline & & & \multicolumn{2}{|l|}{$(-0.02)$} & \multicolumn{2}{|l|}{$(-0.11)$} \\
\hline \multirow[t]{2}{*}{ Population (1789) } & & & \multicolumn{2}{|l|}{$-0.359^{*}$} & \multicolumn{2}{|l|}{$-0.579 * *$} \\
\hline & & & \multicolumn{2}{|l|}{$(-1.82)$} & \multicolumn{2}{|l|}{$(-2.28)$} \\
\hline \multirow[t]{2}{*}{ Literacy (1686-1690) } & & & & -0.014 & 0.003 & \\
\hline & & & & $(-1.44)$ & $(0.22)$ & \\
\hline Constant & $2.984 * * *$ & $36.412 * * *$ & $7.271^{* * *}$ & $3.889 * * *$ & $35.562^{*}$ & $2.028 * * *$ \\
\hline & $(9.27)$ & $(2.62)$ & $(3.64)$ & $(10.40)$ & $(1.75)$ & (6.39) \\
\hline Observations & 708 & 682 & 674 & 605 & 597 & 708 \\
\hline$R^{2}$ & 0.5427 & 0.4033 & 0.3892 & 0.4009 & 0.4280 & 0.3169 \\
\hline
\end{tabular}

Note: All variables except the dummies and rates are in logarithm. The dependent variable is the enrolment in adult courses (in log). Columns (1) to (5) report OLS estimates. Column (6) reports Fixed effect estimates. Column (2) reports estimates of Equation (1) when geographical controls are included. Column (3) reports estimates of Equation (1) when population controls are included. Column (4) reports estimates of Equation (1) when pre-development controls are included. Column (5) reports estimates of Equation (1) when all controls are included. T-statistics are reported in brackets. ${ }^{* * *}$ indicates significance at the $1 \%$-level, $* *$ indicates significance at the $5 \%$-level, * indicates significance at the $10 \%$-level.

Table 3. The effect of industrialization on basic vs. intermediate human capital (1839)

\begin{tabular}{|c|c|c|c|c|c|}
\hline & (1) & (2) & (3) & (4) & (5) \\
\hline & $\begin{array}{c}\text { Number of } \\
\text { men in EPS } \\
(1840)\end{array}$ & $\begin{array}{l}\text { Number of men } \\
\text { in classes for } \\
\text { adults (1837) }\end{array}$ & $\begin{array}{l}\text { Proportion of } \\
\text { conscripts } \\
(1851-55)\end{array}$ & $\begin{array}{c}\text { Schools per } \\
10,000 \\
\text { inhabitants } \\
\text { (1837) }\end{array}$ & $\begin{array}{c}\text { Number of } \\
\text { Municipalities } \\
\text { with no school } \\
\text { (1837) }\end{array}$ \\
\hline & \multicolumn{5}{|c|}{ OLS (no control) } \\
\hline \multirow{2}{*}{$\begin{array}{l}\text { Number of } \\
\text { steam } \\
\text { engines }\end{array}$} & $0.396 * * *$ & $0.587 * * *$ & $2.036 * * *$ & $0.154 * * *$ & $-3.847 * * *$ \\
\hline & (3.89) & (3.55) & (3.05) & (5.67) & $(-4.47)$ \\
\hline \multirow[t]{2}{*}{ Constant } & $3.515^{* * *}$ & $2.692 * * *$ & $78.199 * * *$ & $5.999 * * *$ & $26.022 * * *$ \\
\hline & (11.75) & (5.82) & (39.97) & (81.08) & (9.65) \\
\hline Observations & 87 & 86 & 85 & 86 & 86 \\
\hline \multirow[t]{2}{*}{ r2 } & 0.132 & 0.104 & 0.083 & 0.241 & 0.127 \\
\hline & \multicolumn{5}{|c|}{ OLS (with controls) } \\
\hline Number of & 0.033 & -0.285 & 0.986 & $0.098 * *$ & $-2.798^{*}$ \\
\hline
\end{tabular}




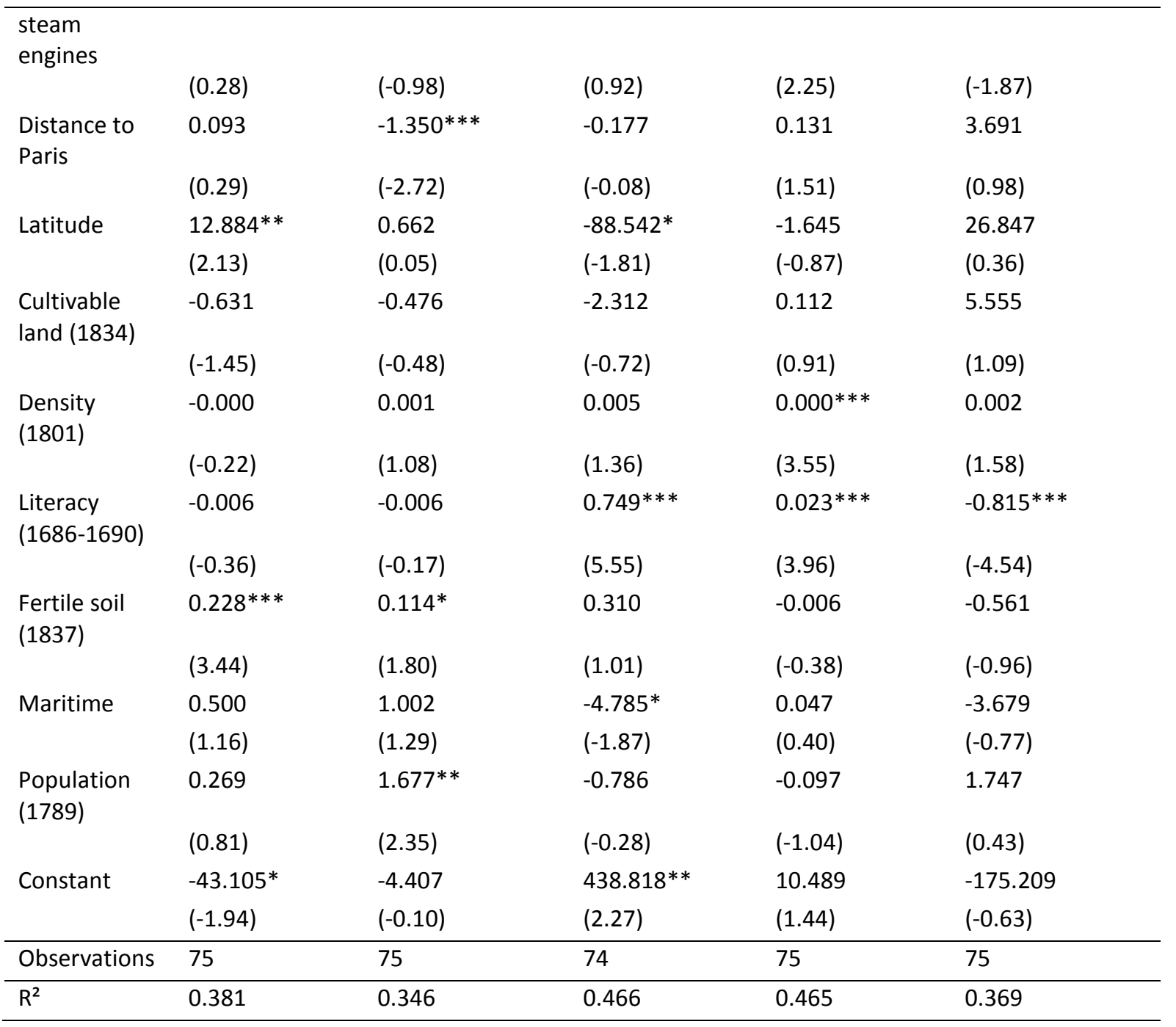

Note: All variables except the dummies and rates are in logarithm. The dependent variable is the number of steam engines in use in French industries at the department level in 1839. T-statistics are reported in brackets. $* * *$ indicates significance at the $1 \%$-level, $* *$ indicates significance at the $5 \%$-level, * indicates significance at the $10 \%$-level.

Table 4. The effect of industrialization on basic vs. intermediate human capital (1861)

\begin{tabular}{|c|c|c|c|c|c|}
\hline & (1) & (2) & (3) & (4) & (5) \\
\hline & $\begin{array}{c}\text { Number of } \\
\text { people in EPS } \\
(1882)\end{array}$ & $\begin{array}{l}\text { Number of } \\
\text { people in } \\
\text { classes for } \\
\text { adults (1863) }\end{array}$ & $\begin{array}{c}\text { Proportion of } \\
\text { conscripts } \\
(1871-75)\end{array}$ & $\begin{array}{c}\text { Schools per } \\
10,000 \\
\text { inhabitants } \\
(1863)\end{array}$ & $\begin{array}{c}\text { Number of } \\
\text { Municipalities } \\
\text { with no school } \\
\text { (1863) }\end{array}$ \\
\hline & \multicolumn{5}{|c|}{ OLS (no control) } \\
\hline \multirow{2}{*}{$\begin{array}{l}\text { Number of } \\
\text { steam } \\
\text { engines }\end{array}$} & $0.519 * * *$ & $0.550 * * *$ & $4.211 * * *$ & $0.121 * * *$ & -0.389 \\
\hline & (4.65) & $(4.44)$ & (3.50) & $(5.53)$ & $(-1.45)$ \\
\hline \multirow[t]{2}{*}{ Constant } & $2.777 * * *$ & $4.210 * * *$ & $48.119 * * *$ & $6.084 * * *$ & $3.853 * * *$ \\
\hline & $(5.28)$ & (7.37) & (8.63) & $(64.64)$ & $(2.84)$ \\
\hline Observations & 86 & 89 & 86 & 89 & 89 \\
\hline \multirow[t]{2}{*}{$r 2$} & 0.230 & 0.286 & 0.135 & 0.267 & 0.033 \\
\hline & \multicolumn{5}{|c|}{ OLS (with controls) } \\
\hline
\end{tabular}




\begin{tabular}{|c|c|c|c|c|c|}
\hline $\begin{array}{l}\text { Number of } \\
\text { steam } \\
\text { engines }\end{array}$ & $0.376 * *$ & (1.31) & $2.539 * *$ & $0.075^{* * *}$ & $(-0.95)$ \\
\hline \multirow{2}{*}{$\begin{array}{l}\text { Distance to } \\
\text { Paris }\end{array}$} & -0.176 & -0.430 & 0.941 & $0.181^{* * *}$ & 0.014 \\
\hline & $(-0.58)$ & $(-1.19)$ & $(0.44)$ & $(2.81)$ & $(0.01)$ \\
\hline \multirow[t]{2}{*}{ Latitude } & -4.674 & 0.387 & $-102.410^{* *}$ & -1.430 & -28.655 \\
\hline & $(-0.53)$ & $(0.09)$ & $(-2.36)$ & $(-1.14)$ & $(-1.30)$ \\
\hline \multirow{2}{*}{$\begin{array}{l}\text { Cultivable } \\
\text { land (1834) }\end{array}$} & 0.011 & 0.385 & -2.905 & $0.189 * *$ & $3.280 * *$ \\
\hline & $(0.02)$ & $(0.86)$ & $(-0.99)$ & $(2.34)$ & $(2.27)$ \\
\hline \multirow{2}{*}{$\begin{array}{l}\text { Density } \\
\text { (1801) }\end{array}$} & -0.000 & 0.001 & 0.005 & $0.000 * * *$ & -0.000 \\
\hline & $(-0.26)$ & $(1.61)$ & (1.28) & (4.69) & $(-0.41)$ \\
\hline \multirow{2}{*}{$\begin{array}{l}\text { Literacy } \\
(1686-1690)\end{array}$} & -0.003 & -0.031 & $0.785^{* * *}$ & $0.018 * * *$ & $-0.066^{*}$ \\
\hline & $(-0.19)$ & $(-1.47)$ & (6.41) & (5.75) & $(-1.91)$ \\
\hline \multirow{2}{*}{$\begin{array}{l}\text { Population } \\
\text { (1789) }\end{array}$} & $0.904 * *$ & $0.543^{*}$ & -2.121 & -0.028 & 0.187 \\
\hline & $(2.30)$ & (1.98) & $(-0.84)$ & $(-0.48)$ & $(0.22)$ \\
\hline \multirow{2}{*}{$\begin{array}{l}\text { Fertile soil } \\
\text { (1837) }\end{array}$} & -0.042 & 0.072 & 0.317 & -0.009 & 0.020 \\
\hline & $(-0.85)$ & (1.19) & $(1.10)$ & $(-1.26)$ & $(0.13)$ \\
\hline \multirow[t]{2}{*}{ Maritime } & -0.770 & $0.801 * *$ & $-4.568 *$ & 0.003 & 1.726 \\
\hline & $(-1.63)$ & $(2.36)$ & $(-1.88)$ & $(0.04)$ & (1.17) \\
\hline \multirow[t]{2}{*}{ Constant } & 13.765 & -4.813 & $498.088 * * *$ & 8.028 & 73.746 \\
\hline & $(0.40)$ & $(-0.25)$ & $(2.86)$ & (1.65) & $(0.89)$ \\
\hline Observations & 74 & 75 & 74 & 75 & 75 \\
\hline $\mathrm{R}^{2}$ & 0.365 & 0.461 & 0.518 & 0.620 & 0.239 \\
\hline
\end{tabular}

Note: All variables except the dummies and rates are in logarithm. The dependent variable is the number of steam engines in use in French industries at the department level in 1861. T-statistics are reported in brackets. $* * *$ indicates significance at the $1 \%$-level, $* *$ indicates significance at the $5 \%$-level, ${ }^{*}$ indicates significance at the 10\%-level.

Table 5. The effect of industrialization on basic vs. intermediate human capital (1886)

\begin{tabular}{|c|c|c|c|c|c|}
\hline & (1) & (2) & (3) & (4) & (5) \\
\hline & $\begin{array}{c}\text { Number of } \\
\text { people in EPS } \\
(1886)\end{array}$ & $\begin{array}{l}\text { Number of } \\
\text { people in } \\
\text { classes for } \\
\text { adults (1886) }\end{array}$ & $\begin{array}{l}\text { Proportion of } \\
\text { conscripts } \\
(1896)\end{array}$ & $\begin{array}{l}\text { Schools per } 10,000 \\
\text { inhabitants }(1896)\end{array}$ & $\begin{array}{c}\text { Number of } \\
\text { Municipalities } \\
\text { with no } \\
\text { school (1896) }\end{array}$ \\
\hline & \multicolumn{5}{|c|}{ OLS (no control) } \\
\hline \multirow{2}{*}{$\begin{array}{l}\text { Number of } \\
\text { steam } \\
\text { engines }\end{array}$} & $0.677^{* * *}$ & $1.501^{* * *}$ & $0.955^{* *}$ & $0.249 * * *$ & 0.013 \\
\hline & (5.11) & $(5.48)$ & $(2.16)$ & $(4.41)$ & $(0.73)$ \\
\hline \multirow[t]{2}{*}{ Constant } & $1.501^{*}$ & $-3.055^{*}$ & $89.393 * * *$ & -0.190 & 0.059 \\
\hline & $(1.82)$ & $(-1.82)$ & $(31.44)$ & $(-0.56)$ & $(0.58)$ \\
\hline Observations & 86 & 87 & 86 & 87 & 86 \\
\hline \multirow[t]{2}{*}{$r 2$} & 0.348 & 0.352 & 0.065 & 0.176 & 0.003 \\
\hline & \multicolumn{5}{|c|}{ OLS (with controls) } \\
\hline
\end{tabular}




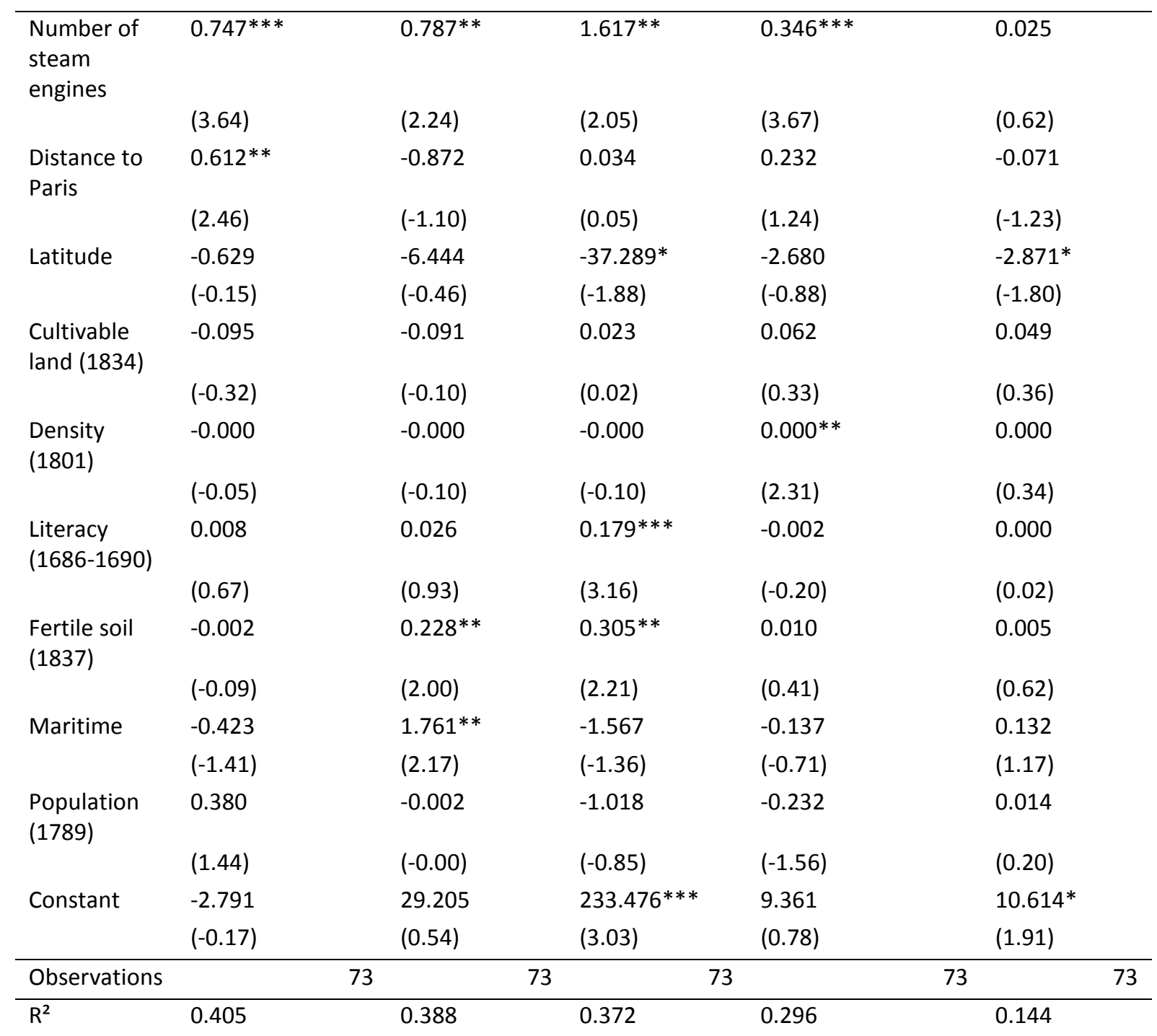

Note: All variables except the dummies and rates are in logarithm. The dependent variable is the number of steam engines in use in French industries at the department level in 1886. T-statistics are reported in brackets. ${ }^{* * *}$ indicates significance at the $1 \%$-level, ${ }^{* *}$ indicates significance at the $5 \%$-level, ${ }^{*}$ indicates significance at the $10 \%$-level.

Robustness checks

Table 6: The geographical diffusion of the steam engine

\begin{tabular}{lllll}
\hline & Panel data & \multicolumn{3}{c}{ Cross section data } \\
\hline & $1839-1900$ & \multicolumn{2}{c}{1839} & \multicolumn{2}{c}{1861} & 1886 \\
\hline Distance to Fresnes & $-1.048^{* * *}$ & $-1.508^{* * *}$ & $-1.586^{* * *}$ & $-1.120^{* * *}$ \\
& $(-7.25)$ & $(-7.86)$ & $(-7.44)$ & $(-5.78)$ \\
Constant & $10.758^{* * *}$ & $11.130^{* * *}$ & $13.748^{* * *}$ & $12.482^{* * *}$ \\
& $(13.01)$ & $(9.65)$ & $(11.18)$ & $(10.97)$ \\
& & & & \\
\hline Observations & 5023 & 87 & 88 & 74 \\
$\mathrm{R}^{2}$ & 0.1057 & 0.340 & 0.314 & 0.247 \\
\hline \multirow{5}{*}{ Oistance to Fresnes } & $-0.722^{* *}$ & $-1.201^{* * *}$ & $-1.292^{* * *}$ & $-1.833^{* * *}$ \\
& $(-2.12)$ & $(-4.09)$ & $(-2.81)$ & $(-6.55)$
\end{tabular}




\begin{tabular}{|c|c|c|c|c|}
\hline \multirow[t]{2}{*}{ Distance to Paris } & -0.032 & -0.022 & 0.144 & 0.301 \\
\hline & $(-0.18)$ & $(-0.11)$ & (0.59) & $(0.98)$ \\
\hline \multirow[t]{2}{*}{ Latitude } & 1.295 & -2.149 & 2.160 & $-5.575^{*}$ \\
\hline & $(0.29)$ & $(-0.36)$ & $(0.35)$ & $(-1.98)$ \\
\hline \multirow[t]{2}{*}{ Literacy (1686-1690) } & -0.019 & -0.009 & -0.020 & $-0.030 * *$ \\
\hline & $(-1.56)$ & $(-0.77)$ & $(-1.21)$ & $(-2.61)$ \\
\hline \multirow[t]{2}{*}{ Maritime } & -0.213 & -0.469 & -0.467 & 0.365 \\
\hline & $(-1.05)$ & $(-1.58)$ & $(-1.62)$ & (1.57) \\
\hline \multirow[t]{2}{*}{ Population (1789) } & $0.911^{* * *}$ & $1.194^{* * *}$ & $1.212 * * *$ & $0.707^{* * *}$ \\
\hline & $(5.24)$ & $(5.36)$ & $(4.86)$ & $(4.37)$ \\
\hline \multirow[t]{2}{*}{ Fertile soil (1837) } & 0.033 & $0.057^{* *}$ & 0.013 & 0.026 \\
\hline & $(1.47)$ & $(2.25)$ & $(0.40)$ & (1.18) \\
\hline \multirow[t]{2}{*}{ Cultivable land 51834) } & 0.260 & -0.348 & 0.192 & $0.765 * * *$ \\
\hline & $(0.88)$ & $(-1.09)$ & $(0.47)$ & $(2.95)$ \\
\hline \multirow[t]{2}{*}{ Density (1801) } & -0.000 & $0.001 * *$ & $0.001^{*}$ & -0.000 \\
\hline & $(-0.18)$ & $(2.02)$ & $(1.76)$ & $(-0.50)$ \\
\hline \multirow[t]{2}{*}{ Constant } & -8.478 & 8.691 & -12.275 & $20.559 *$ \\
\hline & $(-0.42)$ & $(0.36)$ & $(-0.48)$ & $(1.81)$ \\
\hline Observations & 4233 & 75 & 74 & 61 \\
\hline$R^{2}$ & 0.1974 & 0.610 & 0.616 & 0.668 \\
\hline
\end{tabular}

Notes: All variables except the dummies and rates are in logarithm. The dependent variable is the Number of steam engines (in log). Aerial distances are measured in kilometers. T-statistics are reported in brackets. ${ }^{* * *}$ indicates significance at the $1 \%$-level, $* *$ indicates significance at the $5 \%$-level, ${ }^{*}$ indicates significance at the 10\%-level.

Table 7: Pre-industrial development and the distance from Fresnes-sur-Escaut

\begin{tabular}{|c|c|c|c|c|}
\hline & (1) & $(2)$ & (3) & (4) \\
\hline & \multicolumn{4}{|c|}{ Dependent variable: number of steam engines (in log) } \\
\hline & \multicolumn{4}{|c|}{ OLS } \\
\hline & $\begin{array}{c}\text { Population } \\
\text { density, } 1801\end{array}$ & $\begin{array}{c}\text { Literacy, } \\
1686-1690\end{array}$ & $\begin{array}{c}\text { Population } \\
\text { density, } 1801\end{array}$ & $\begin{array}{c}\text { Literacy, } \\
1686-1690 \\
\end{array}$ \\
\hline \multirow[t]{2}{*}{ Distance to Fresnes } & -0.136 & -0.213 & 0.027 & -0.126 \\
\hline & $(-1.07)$ & $(-0.79)$ & $(0.17)$ & $(-0.48)$ \\
\hline \multirow[t]{2}{*}{ Latitude } & $8.011 * *$ & $5.058 *$ & $5.676^{*}$ & 3.555 \\
\hline & $(2.62)$ & $(1.79)$ & $(1.80)$ & $(1.44)$ \\
\hline \multirow[t]{2}{*}{ Cultivable land } & -0.413 & -0.071 & $-0.299 * *$ & -0.153 \\
\hline & $(-1.47)$ & $(-0.34)$ & $(-2.08)$ & $(-0.72)$ \\
\hline \multirow[t]{2}{*}{ Fertile soil } & -0.014 & 0.015 & -0.005 & 0.020 \\
\hline & $(-0.91)$ & (1.00) & $(-0.35)$ & $(1.45)$ \\
\hline \multirow[t]{2}{*}{ Distance to Paris } & & & $-0.265^{* *}$ & $-0.255^{*}$ \\
\hline & & & $(-2.10)$ & $(-1.89)$ \\
\hline \multirow[t]{2}{*}{ Constant } & -18.104 & -14.668 & -10.053 & -6.994 \\
\hline & $(-1.59)$ & $(-1.23)$ & $(-0.78)$ & $(-0.70)$ \\
\hline Observations & 85 & 76 & 85 & 76 \\
\hline $\mathrm{R}^{2}$ & 0.177 & 0.348 & 0.210 & 0.381 \\
\hline
\end{tabular}

Notes: All variables except the dummies and rates are in logarithm. Aerial distances from Fresnes and from Paris are measured in kilometers. T-statistics are reported in brackets. ${ }^{* * *}$ indicates significance at the $1 \%$-level, $* *$ indicates significance at the $5 \%$-level, * indicates significance at the $10 \%$-level.

Table 8.a. The effect of industrialization on intermediate human capital (2SLS estimates panel data)

$\begin{gathered}\text { Dependent variable: Enrolments in EPS } \\ \text { (in log) }\end{gathered}$
Dependent variable: enrolments in adult
classes (in log)




\begin{tabular}{|c|c|c|c|c|}
\hline & No control & All controls & No control & All controls \\
\hline & & & $2 S L S$ & \\
\hline \multirow[t]{2}{*}{$\begin{array}{l}\text { Number of steam } \\
\text { engines }\end{array}$} & $0.505^{* * *}$ & $0.593^{* *}$ & $0.436 * * *$ & 0.151 \\
\hline & $(4.90)$ & (2.18) & (3.34) & $(0.51)$ \\
\hline Controls & No & Yes & No & Yes \\
\hline Observations & 602 & 520 & 708 & 597 \\
\hline \multirow[t]{2}{*}{ Distance to Fresnes } & $-1.149 * * *$ & $-.857 * *$ & $-1.478 * * *$ & $-.932 * * *$ \\
\hline & $(-6.38)$ & $(-2.44)$ & $(-10.35)$ & $(-4.65)$ \\
\hline F-stat ( $1^{\text {st }}$ Stage $)$ & 107.09 & 25.39 & 40.68 & 5.95 \\
\hline
\end{tabular}

Note: All variables except the dummies and rates are in logarithm. The Number of steam engines, in log, is instrumented with the Distance to Fresnes, measured in kilometers. T-statistics are reported in brackets. ${ }^{* * *}$ indicates significance at the $1 \%$-level, ${ }^{* *}$ indicates significance at the $5 \%$-level, ${ }^{*}$ indicates significance at the 10\%-level.

Table 8.b. The effect of industrialization on intermediate human capital (2SLS estimates panel data) during the second half of nineteenth century

\begin{tabular}{|c|c|c|}
\hline & \multicolumn{2}{|c|}{ Dependent variable: enrolments in adult classes (in log) } \\
\hline & Post-1863 & Post-1867 \\
\hline & \multicolumn{2}{|c|}{$2 S L S$} \\
\hline \multirow[t]{2}{*}{ Number of steam engines } & $0.402^{* *}$ & $0.408^{*}$ \\
\hline & $(2.15)$ & $(1.73)$ \\
\hline Controls & Yes & Yes \\
\hline Observations & 447 & 372 \\
\hline \multirow[t]{2}{*}{ Distance to Fresnes } & $-0.874^{* * *}$ & $-0.881 * * *$ \\
\hline & $(-6.10)$ & $(-3.20)$ \\
\hline F-stat $\left(1^{\text {st }}\right.$ Stage $)$ & 37.20 & 10.23 \\
\hline
\end{tabular}

Note: All variables except the dummies and rates are in logarithm. The Number of steam engines, in log, is instrumented with the Distance to Fresnes, measured in kilometers. T-statistics are reported in brackets. ${ }^{* * *}$ indicates significance at the $1 \%$-level, ${ }^{* *}$ indicates significance at the $5 \%$-level, ${ }^{*}$ indicates significance at the $10 \%$-level.

Table 9: The effect of industrialization on human skills in 1839 (2SLS)

\begin{tabular}{|c|c|c|c|c|c|}
\hline & (1) & (2) & (3) & (4) & (5) \\
\hline & $\begin{array}{c}\text { Proportion of } \\
\text { conscripts in } \\
1851-1855\end{array}$ & $\begin{array}{c}\text { Schools per } \\
10,000 \\
\text { inhabitants } 1837\end{array}$ & $\begin{array}{c}\text { Number of } \\
\text { Municipalities with } \\
\text { no school in } 1837\end{array}$ & $\begin{array}{c}\text { Number of } \\
\text { men in EPS in } \\
1840\end{array}$ & $\begin{array}{l}\text { Number of men } \\
\text { in classes for } \\
\text { adults in } 1837\end{array}$ \\
\hline & \multicolumn{5}{|c|}{$2 \mathrm{SLS}$} \\
\hline \multirow[t]{2}{*}{$\begin{array}{l}\text { Number of } \\
\text { steam engines }\end{array}$} & $0.043^{*}$ & $0.229^{* *}$ & $-1.116^{* * *}$ & 0.283 & 0.385 \\
\hline & $(1.75)$ & (2.38) & $(-3.67)$ & (1.17) & (1.04) \\
\hline Controls & Yes & Yes & Yes & Yes & Yes \\
\hline Distance & $-1.376^{* * *}$ & $-1.376 * * *$ & $-1.376 * * *$ & $-1.376^{* * *}$ & $-1.376 * * *$ \\
\hline Fresnes & $(-3.56)$ & $(-3.56)$ & $(-3.56)$ & $(-3.56)$ & $(-3.56)$ \\
\hline Observations & 74 & 75 & 75 & 75 & 75 \\
\hline $\begin{array}{l}\text { F-stat }\left(1^{\text {st }}\right. \\
\text { Stage) }\end{array}$ & 12.59 & 12.66 & 12.66 & 12.66 & 12.66 \\
\hline
\end{tabular}




$\begin{array}{llllll}\text { Observations } & 74 & 75 & 75 & 75 & 75\end{array}$

Notes: All variables except the dummies and rates are in logarithm. Columns (1) to (5) report 2SLS estimates of Equation (1) using all controls. Number of steam engines is the log of the number of steam engines recorded in 1839. It is instrumented with Distance to Fresnes, measured in kilometers. T-statistics are reported in brackets. ${ }^{* * *}$ indicates significance at the $1 \%$ level, ${ }^{* *}$ indicates significance at the $5 \%$-level, * indicates significance at the $10 \%$-level.

Table 10: The effect of industrialization on human skills in 1861 (2SLS)

\begin{tabular}{|c|c|c|c|c|c|}
\hline & (1) & $(2)$ & (3) & (4) & (5) \\
\hline & $\begin{array}{l}\text { Proportion of } \\
\text { conscripts in } \\
1871-1875\end{array}$ & $\begin{array}{c}\text { Schools per } \\
10,000 \\
\text { inhabitants in } \\
1863 \\
\end{array}$ & $\begin{array}{c}\text { Number of } \\
\text { Municipalities with } \\
\text { no school in } 1863\end{array}$ & $\begin{array}{l}\text { Number of } \\
\text { individuals in } \\
\text { EPS in } 1882\end{array}$ & $\begin{array}{c}\text { Number of } \\
\text { individuals in } \\
\text { classes for adults } \\
\text { in } 1863\end{array}$ \\
\hline & \multicolumn{5}{|c|}{$2 S L S$} \\
\hline \multirow[t]{2}{*}{$\begin{array}{l}\text { Number of } \\
\text { steam engines }\end{array}$} & $0.115^{*}$ & $0.125^{*}$ & $-0.631 * *$ & $1.236 * * *$ & $0.470 * *$ \\
\hline & (1.95) & (1.74) & $(-2.03)$ & (3.24) & $(2.44)$ \\
\hline All controls & Yes & Yes & Yes & Yes & Yes \\
\hline Distance to & $-1.1164 * * *$ & $-1.1164 * * *$ & $-1.1164^{* * *}$ & $-1.1201 * * *$ & $-1.1164 * * *$ \\
\hline Fresnes & $(-3.90)$ & (3.90) & $(-3.90)$ & $(-3.93)$ & $(-3.90)$ \\
\hline $\begin{array}{l}\text { F-stat }\left(1^{\text {st }}\right. \\
\text { Stage) }\end{array}$ & 15.24 & 15.24 & 15.24 & 15.42 & 15.24 \\
\hline Observations & 75 & 75 & 75 & 74 & 75 \\
\hline
\end{tabular}

Notes: All variables except the dummies and rates are in logarithm. Columns (1) to (5) report 2SLS estimates of Equation (1) using all controls. Number of steam engines is the log of the number of steam engines recorded in 1861. It is instrumented with Distance to Fresnes, measured in kilometers. T-statistics are reported in brackets. ${ }^{* * *}$ indicates significance at the $1 \%$ level, ${ }^{* *}$ indicates significance at the $5 \%$-level, * indicates significance at the $10 \%$-level.

Table 11: The effect of industrialization on human skills in 1886 (2SLS)

\begin{tabular}{|c|c|c|c|c|c|}
\hline & (1) & (2) & (3) & (4) & (5) \\
\hline & $\begin{array}{c}\text { Proportion of } \\
\text { conscripts in } \\
1886\end{array}$ & $\begin{array}{c}\text { Schools per } \\
10,000 \\
\text { inhabitants in } \\
1886\end{array}$ & $\begin{array}{c}\text { Number of } \\
\text { Municipalities with } \\
\text { no school in } 1886\end{array}$ & $\begin{array}{l}\text { Number of } \\
\text { individuals in } \\
\text { EPS in } 1886\end{array}$ & $\begin{array}{c}\text { Number of } \\
\text { individuals in } \\
\text { classes for adults } \\
\text { in } 1886\end{array}$ \\
\hline & \multicolumn{5}{|c|}{$2 S L S$} \\
\hline \multirow[t]{2}{*}{$\begin{array}{l}\text { Number of } \\
\text { steam engines }\end{array}$} & 2.632 & 0.083 & -0.122 & $0.874^{* * *}$ & $1.225^{* *}$ \\
\hline & (1.25) & $(0.92)$ & $(-0.60)$ & (3.55) & $(2.14)$ \\
\hline Distance to & $-0.9042 * * *$ & $-0.9113 * * *$ & $-0.9113 * * *$ & $-0.9042 * * *$ & $-0.9042 * * *$ \\
\hline Fresnes & $(-3.96)$ & $(-3.97)$ & $(-3.97)$ & $(-3.96)$ & $(-3.96)$ \\
\hline $\begin{array}{l}\text { F-stat (1st } \\
\text { Stage) }\end{array}$ & 15.69 & 15.78 & 15.78 & 15.69 & 15.69 \\
\hline Observations & 74 & 73 & 73 & 74 & 74 \\
\hline
\end{tabular}

